\title{
Archaeological Investigations at the Redwine Site (41SM193), Smith County, Texas
}

Mark Walters

Heritage Research Center, Stephen F. Austin State University

Patti Haskins

David H. Jurney

S. Eileen Goldborer

Timothy K. Perttula Heritage Research Center, Stephen F. Austin State University

Follow this and additional works at: https://scholarworks.sfasu.edu/ita

Part of the American Material Culture Commons, Archaeological Anthropology Commons, Environmental Studies Commons, Other American Studies Commons, Other Arts and Humanities Commons, Other History of Art, Architecture, and Archaeology Commons, and the United States History Commons

Tell us how this article helped you.

This Article is brought to you for free and open access by the Center for Regional Heritage Research at SFA ScholarWorks. It has been accepted for inclusion in Index of Texas Archaeology: Open Access Gray Literature from the Lone Star State by an authorized editor of SFA ScholarWorks. For more information, please contact cdsscholarworks@sfasu.edu. 


\section{Archaeological Investigations at the Redwine Site (41SM193), Smith County, \\ Texas}

\section{Creative Commons License}

\section{(c) (1) (8)}

This work is licensed under a Creative Commons Attribution-NonCommercial 4.0 International License 


\title{
ARCHAEOLOGICAL INVESTIGATIONS AT THE REDWINE SITE (41SM193), SMITH COUNTY, TEXAS
}

\author{
Mark Walters and Patti Haskins, with contributions by David H. Jurney, \\ $S$. Eileen Goldborer, and Timothy $K$. Perttula
}

\section{Introduction}

The Redwine site (41SM193) is a probable Middle Caddoan habitation site located on an upland terrace (Figure 1) on the headwaters of Auburn Creek, a small tributary of the Sabine River in central Smith County; the Angelina River drainage basin begins about 1.5 $\mathrm{km}$ to the south of the site. Auburn Creek is about 100 meters to the north of the site. The Sabine River lies approximately $24 \mathrm{~km}$ to the north. Soils on the Redwine site are Bowie fine sandy loam (Hatherly 1993)

The site was discovered in the early 1960 s by Sam Whiteside, an avocational archaeologist who lived in the Tyler area. His work consisted of trenching, and he located and excavated several burials and a small house mound. In an attempt to relocate the site, limited controlled excavations were undertaken in 1995 by the authors, under the direction of Dr. John Keller of Southem Archaeological Consultants, Inc. We hoped to gain enough information about the size, age, and integrity of the Redwine site to apply for legal designation and protection under the Antiquities Code of Texas. After confirming that the Redwine site contained important archaeological information, an application for State Archeological Landmark (SAL) designation was made in 1996, and in July 1996, the Redwine site was officially designated an SAL by the Texas Historical Commission, the first SAL in Smith County. This paper describes our findings, and discusses the artifacts and plant and animal remains recovered during the work. We also provide information on the 1960s excavations of a small house mound at the site, along with the grave goods recovered by Sam Whiteside from the four Redwine site burials.

\section{Investigations}

Our investigations began with a series of shovel tests and a controlled surface collection, working from fixed vertical and horizontal datums. The controlled surface collection (Figure 2) indicated a semi-circular concentration of artifacts and darkly-stained midden deposits on the crest and western sides of the terrace landform, with Iow densities of materials on the eastern part of the terrace.

Based on the information gathered during this effort, we opened an initial test unit to determine if midden deposits were present and what their integrity might be. In all, we excavated 19 square meters ( 8.8 cubic meters) in a midden area at the Redwine site. The block excavation profile indicated that the plow zone extended from $0-20 \mathrm{~cm}$ in depth, and was underlain by a black sandy loam midden deposit from $20-35 \mathrm{~cm}$ below surface. The midden rested on a reddish-orange clay argillic $\mathrm{B}$ horizon.

Excavations were done in $10 \mathrm{~cm}$ levels, except for the plow zone, which was removed as a single $20 \mathrm{~cm}$-thick level. The soil matrix was screened through $1 / 4$-inch hardware cloth, and all recovered artifacts were bagged and numbered by unit, level, and the date. At the completion of each level, level sheets were prepared showing the locations and sizes of any features that were present. Several flotation samples were obtained from feature and midden deposits, and these were subsequently processed to determine if charred plant remains were preserved at the site (see Goldborer, below). Charred nutshells from one feature were collected as a radiocarbon assay, and subsequently sent to Beta Analytic, Inc. for a radiocarbon date. 


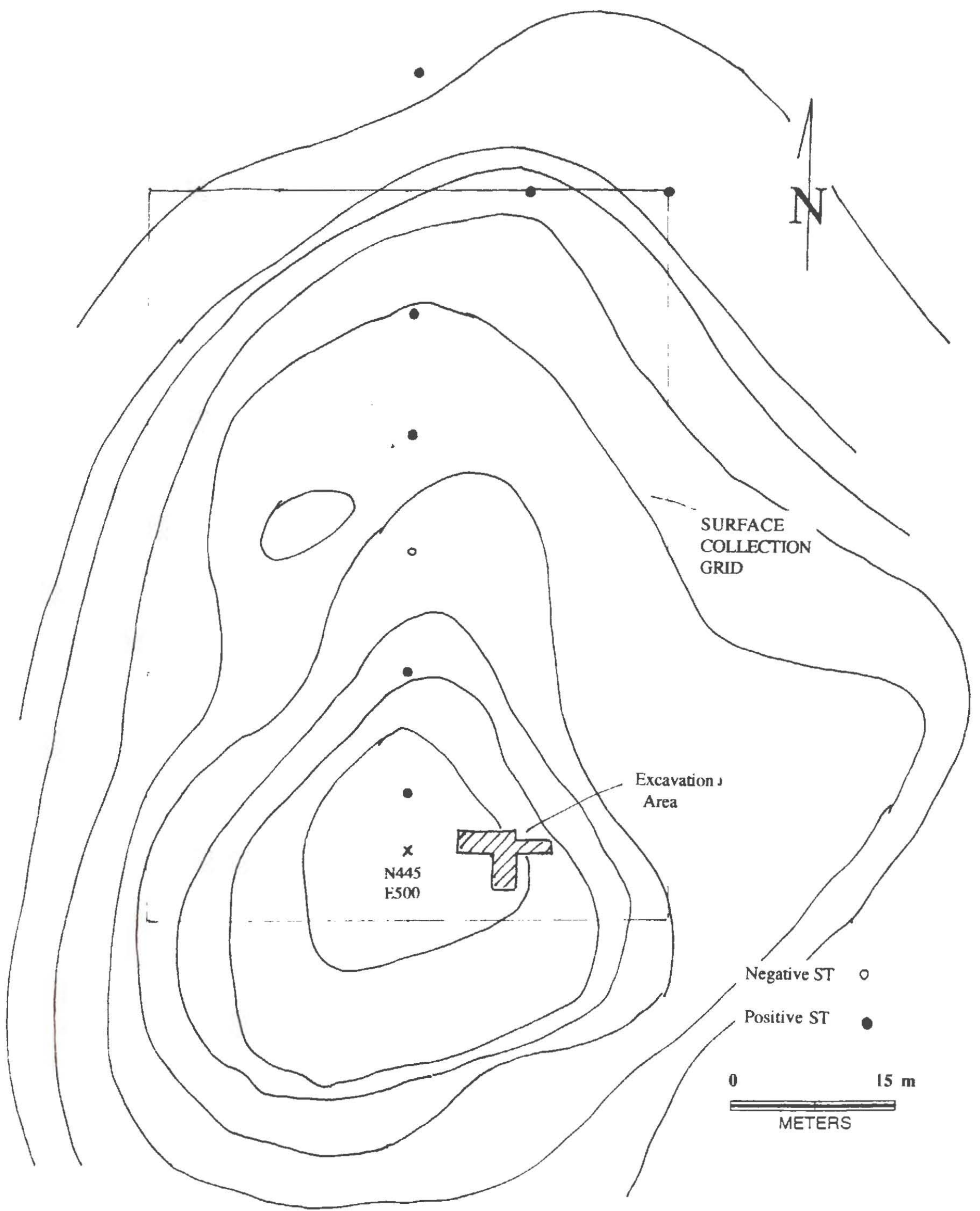

Figure 1. The Redwine Site, Surface Collection Grid, Excavation Area, and Positive and Negative Shovel tests. 


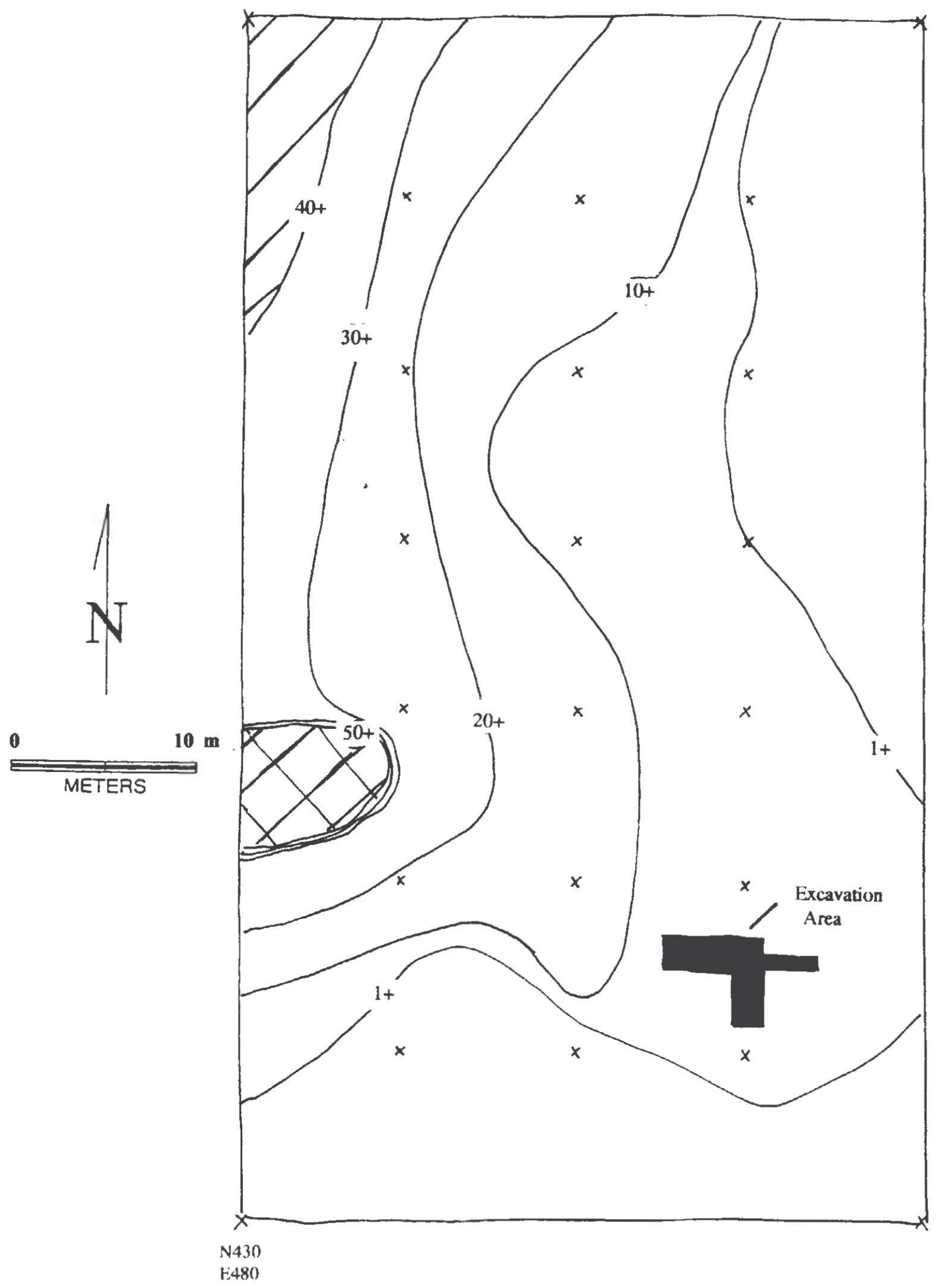

Figure 2. Density of Artifacts (1-50+) per $10 \times 10 \mathrm{~m}$ units in Surface Collection Grid. 


\section{Features}

We recorded seven possible features in the Redwine excavations, four possible postmolds (Features 1-2 and 5-6), a hearth (Feature 3), and two pits (Features 4 and 7). The hearth was exposed in Unit 2 at $30 \mathrm{~cm}$ bs, while the two pits were in Unit 1 (Figure 3 ).

Features 1 and 2 were possible post molds ca. $10 \mathrm{~cm}$ in diameter exposed in Unit 1 at 40 $\mathrm{cm}$ below surface (bs); the stains had disappeared by $50 \mathrm{~cm}$ bs. Artifacts found in apparent association with these features include four decorated sherds, one rim sherd, eight plain sherds, six pieces of burned clay, 73 animal bones, 44 charred nutshells, and four pieces of lithic debris.

The Feature 3 hearth area consisted of a soft gray ash and charcoal-mottled center $(40 \times 28$ $\mathrm{cm}$ in size) surrounded by a hard-packed midden soil (ca. $80 \times 160 \mathrm{~cm}$ in size) that was sometimes brick red to bright yellow in color from intense burning. The top of the hearth was $30 \mathrm{~cm}$ bs, and it was $30 \mathrm{~cm}$ in thickness. Surrounding the hearth was a dense midden deposit, with artifact densities of 1377 artifacts per cubic meter. We recovered no information that the hearth was clay-lined or prepared, and there was no postmold underneath it, as is the case in many Caddoan houses. No postmold pattern of a structure was documented in the units opened around the hearth, and combined with the evidence of intense heat, this suggests that the hearth was an outdoor feature. The presence of burned bone and ceramics associated with the hearth may indicate that the firing of pottery may have taken place at the feature. The hearth matrix was collected for flotation analyses. In addition to animal bone $(n=390)$ and com from the feature, the heavy fraction contained three decorated/rim sherds, 14 plain sherds, 13 pieces of burned clay, and five pieces of daub.

The top of Feature 4 was encountered at $20 \mathrm{~cm}$ bs in the northwest corner of Unit 1. It was about $70 \mathrm{~cm}$ in diameter and contained a large vertical sandstone slab, other rocks, and midden fill (Figure 4). Other smaller rocks were also present, but below $50 \mathrm{~cm}$ only two large vertically-oriented rocks remained in the pit. The largest rock, weighing more than 70 $\mathrm{kg}$, extended to the bottom of the pit at $91 \mathrm{~cm}$ bs. None of the rocks in the pit showed evidence of burning. Recovered in association with Feature 4 were 48 decorated sherds (including seven rim sherds), 76 plain sherds, one piece of burned clay, eight pieces of daub, 15 lithic debris, two arrowpoints, 81 animal bones, and 49 charred nutshells.

Features 5 and 6 were initially considered to be post molds, but Feature 5 was actually a rodent burrow, and the Feature 6 stain disappeared by $50 \mathrm{~cm}$ bs.

Feature 7 was apparently either an un-lined pit or a large post hole with black midden fill; it was found just south of Feature 3 (see Figure 3) at $65 \mathrm{~cm}$ bs, and extended to $90 \mathrm{~cm}$ bs. It contained 13 decorated and/or rim sherds, 21 plain sherds, 13 mussel shell fragments, 128 animal bones, two arrowpoints, one lithic debris, and 154 charred nutshells. Such pits are common in and around Caddoan structures and are generally associated with food storage. The uniform fill contents of the pit, and the lack of special preparation of the pit walls and floors, however, prevent a conclusive determination of its use.

\section{Artifact Assemblage}

More than 5900 artifacts were recovered in our investigations at the Redwine site (Table 1). Approximately 39 percent of the artifacts are ceramic sherds, fired clay, daub, or clay pipe fragments. Animal bone and shell comprised 38 percent of the assemblage, with charred 


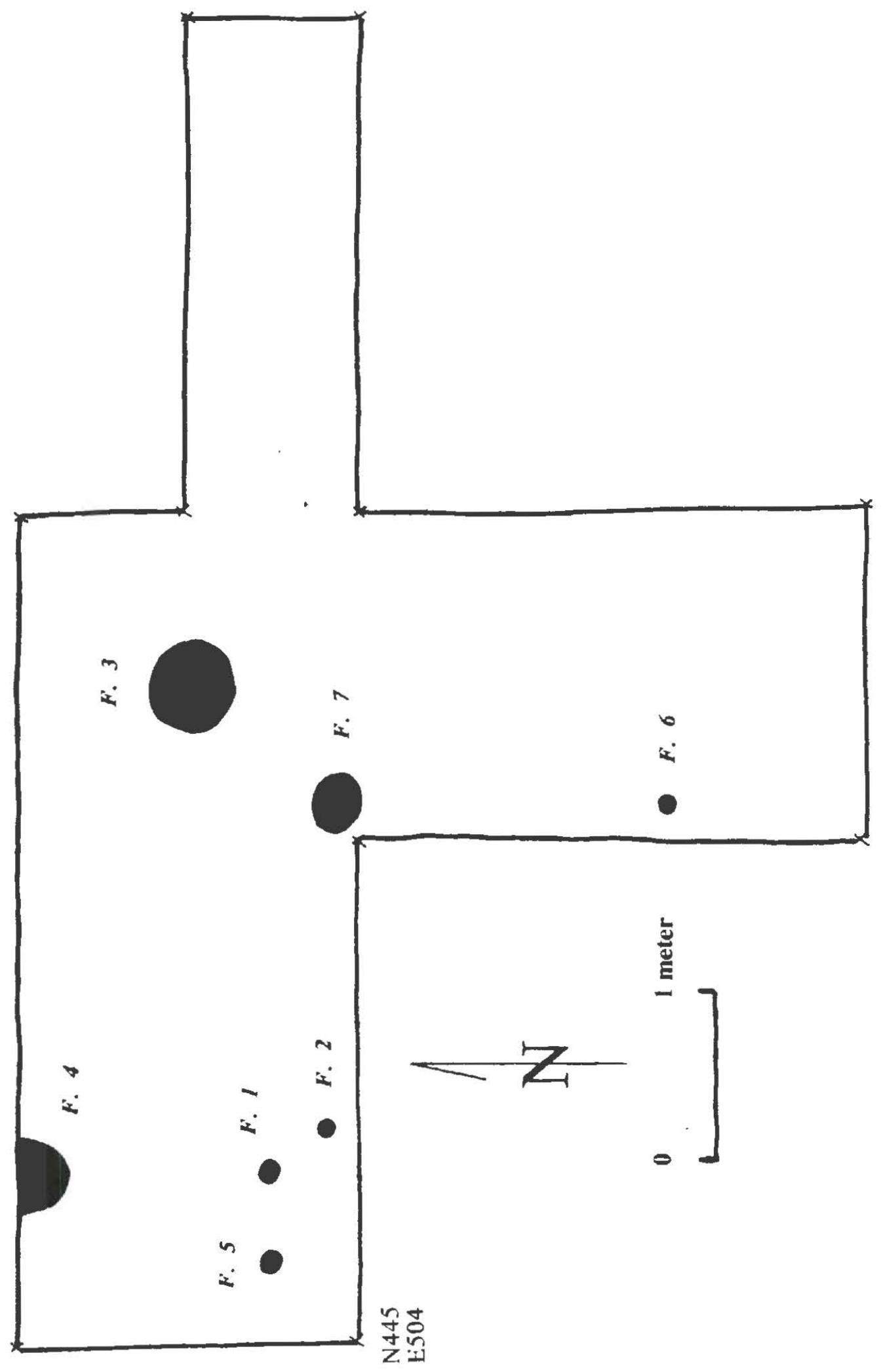

立 


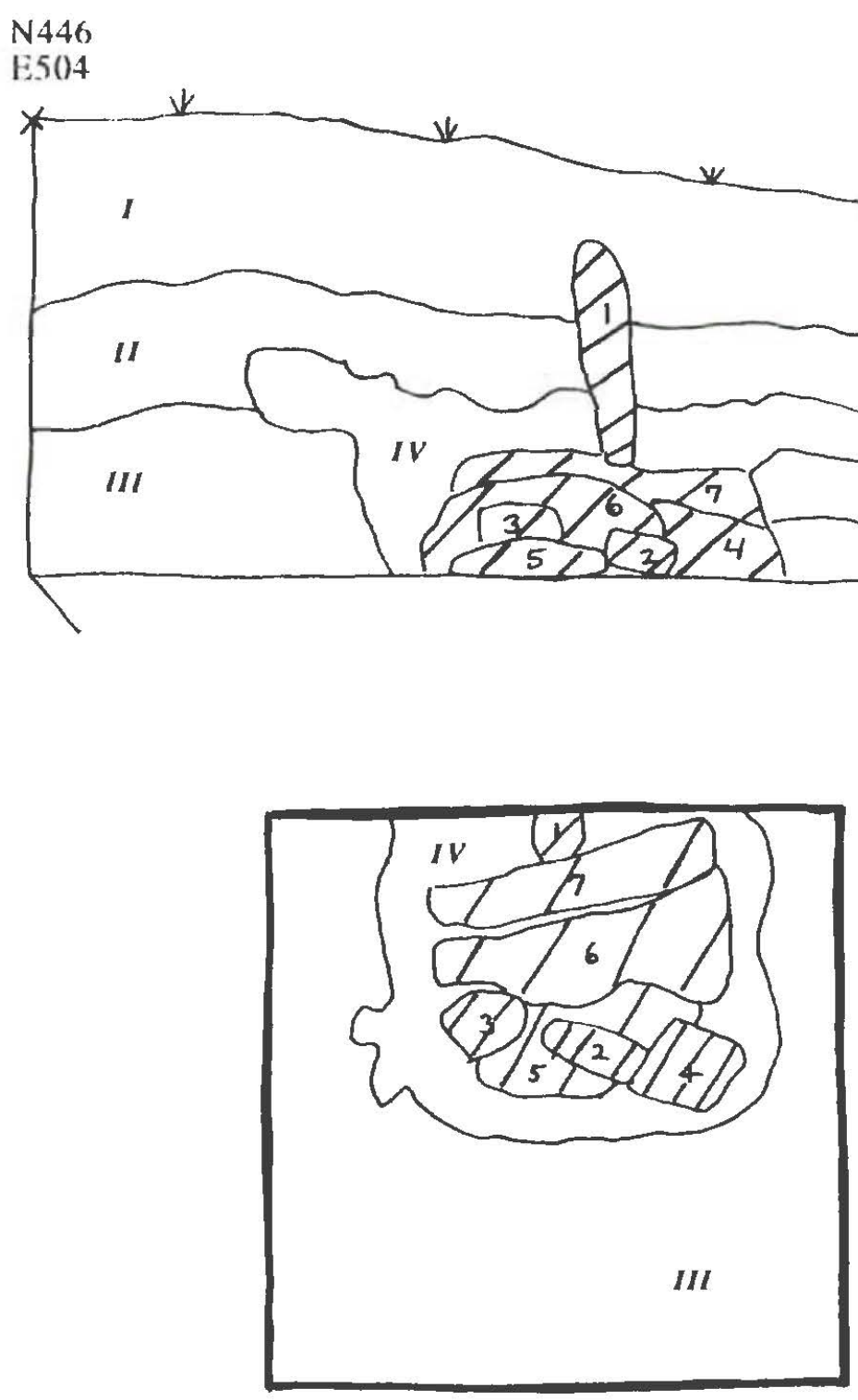

$30 \mathrm{~cm}$ bs

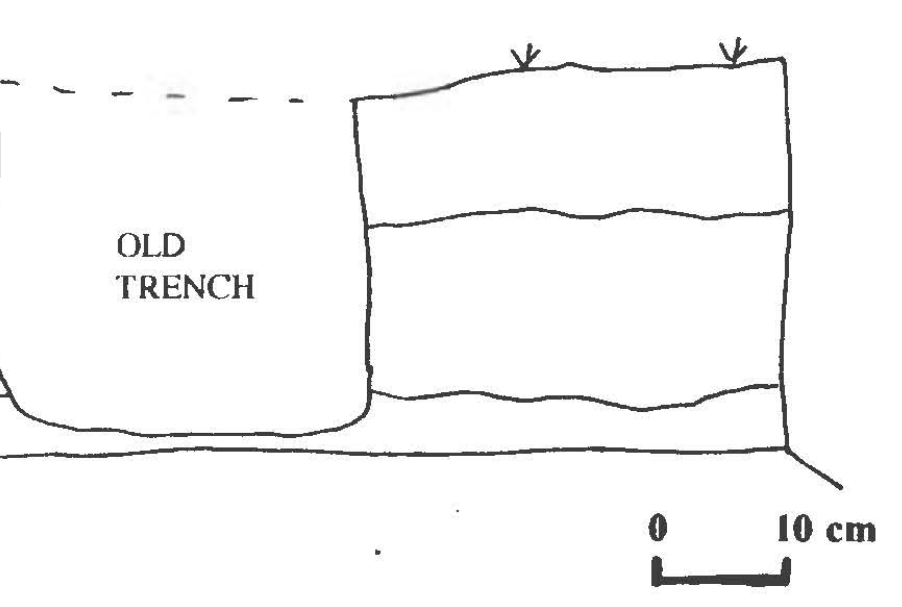

C (harcoal

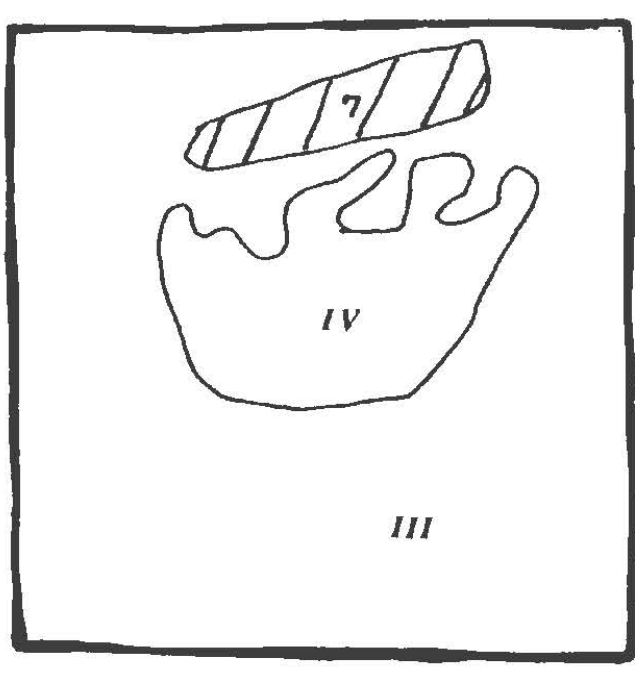

17 sandstonc slabs

$90 \mathrm{~cm}$ bs 
nutshells another 20 percent. Lithic artifacts accounted for less than 3 percent of the Redwine artifact inventory.

Table 1. Artifact Inventory from the Redwine Site (41SM193)

\begin{tabular}{|c|c|c|c|}
\hline CLASS & Type & No. & Percent \\
\hline \multirow[t]{3}{*}{ CERAMICS } & $\begin{array}{l}\text { Decorated Body } \\
\text { Decorated Rim } \\
\text { Plain Sherds } \\
\text { Plain Rims } \\
\text { Fired Clay } \\
\text { Daub } \\
\text { Pipe Fragments }\end{array}$ & $\begin{array}{l}523 \\
74 \\
1339 \\
65 \\
250 \\
26 \\
7\end{array}$ & $\begin{array}{l}8.9 \\
1.3 \\
22.7 \\
1.1 \\
4.2 \\
0.4 \\
0.1\end{array}$ \\
\hline & Total & 2284 & 38.7 \\
\hline & $\begin{array}{l}\text { Total Sherds } \\
\text { Total Decorated } \\
\text { Total Plain }\end{array}$ & $\begin{array}{l}2001 \\
597 \\
1404\end{array}$ & $\begin{array}{l}29.8 \\
70.2\end{array}$ \\
\hline LITHICS & $\begin{array}{l}\text { Hakes } \\
\text { Cores } \\
\text { Points } \\
\text { End Scraper } \\
\text { Celt Fragments } \\
\text { Groundstone } \\
\text { Hammerstone } \\
\text { Fire-cracked rock }\end{array}$ & $\begin{array}{l}122 \\
2 \\
15 \\
1 \\
3 \\
7 \\
1 \\
10\end{array}$ & $\begin{array}{l}2.1 \\
<0.1 \\
0.3 \\
<0.1 \\
<0.1 \\
0.1 \\
<0.1 \\
1.7\end{array}$ \\
\hline FLORA & Charred Nutshells & 1187 & 20.0 \\
\hline FAUNA & Bone and Shell & 2271 & 38.5 \\
\hline TOTALAR'TIFACTS & & 5903 & 100.0 \\
\hline
\end{tabular}

The prehistoric artifacts were concentrated in the plow zone and midden deposits, with more than 83 percent recovered between $0-50 \mathrm{~cm}$ in the excavations. Small amounts of artifacts were found as deep as $90-100 \mathrm{~cm}$ bs, but these were from pit fill contexts.

Ceramic Sherds

Thirty percent of the 2001 Redwine sherds are decorated (see Table 1). Brushing was the most common decoration on body sherds, followed by engraved, punctated, and incised decorative elements, with small amounts of punctated-incised, brushed-punctated, red slipped, and pinched/punctated (Table 2). Of the $139 \mathrm{rim}$ sherds, 46.8 percent were plain, and punctated, incised, and engraved decorations comprise another 39.6 percent (see 'Table 2) of the sample. 
Table 2. Ceramic Decorative Treatment

\begin{tabular}{lllll}
\hline Body Sherds & No./Percent & Rim Sherds & No./Percent \\
\hline & & & & \\
Brushed & $165 / 31.5$ & Plain & $65 / 46.8$ \\
Punctated & $96 / 18.3$ & Punctated & $18 / 13.0$ \\
Engraved & $113 / 21.6$ & Incised & $15 / 10.8$ \\
lncised & $65 / 12.4$ & Engraved & $22 / 15.8$ \\
Punctated-Incised & $34 / 6.5$ & Incised-Punctated & $8 / 5.6$ \\
Brushed-Punctated* & $39 / 7.5$ & Brushed-Punctated* & $7 / 5.0$ \\
Red slipped & $3 / 0.6$ & Red slipped & $3 / 2.2$ \\
Pinched-Punctated & $8 / 1.5$ & Brushed & $1 / 0.7$ \\
\hline
\end{tabular}

* includes four brushed-punctated-ridged sherds

'The frequencies of decorated sherds are quite consistent by depth in the excavations, particularly in the midden deposits $(20-50 \mathrm{~cm}$ bs) (Table 3$)$. Brushed sherds range between 29-30 percent in the heart of the midden; engraved sherds amount to 19-21 percent of the decorated midden sample, and punctated sherds comprise 14-16 percent. The assemblage composition of the Redwine decorated sherds is quite comparable to (and probably contemporaneous with) large Middle Caddoan ceramic assemblages at 41 HS74 (Heartfield, Price, and Greene 1988) and Oak Hill Village (41RK214) in the middle Sabine River drainage in that it has abundant brushing, the virtual absence of red-slipped wares, engraved ladders and scrolls, Pease Brushed-Incised, and cross-hatched incised motifs (Perttula and Cruse 1997:34).

Table 3. Design Elements by Level

\begin{tabular}{|c|c|c|c|c|c|c|c|c|c|c|c|}
\hline I evel & $\mathrm{B}^{*}$ & $P$ & I & $\mathrm{E}$ & $\mathrm{B} / \mathrm{P}$ & $1 / \mathrm{P}$ & $\mathrm{B} / \mathrm{P} / \mathrm{R}$ & $P / R$ & $\mathrm{RS}$ & PR & Totals \\
\hline Surf. & 49 & 43 & 32 & 25 & 4 & 11 & - & 1 & 2 & 15 & 185 \\
\hline $0-20$ & 29 & 25 & 23 & 31 & 2 & 13 & 1 & 4 & - & I0) & 138 \\
\hline $20-30$ & 35 & 17 & 5 & 25 & 8 & 5 & - & 1 & - & 23 & 119 \\
\hline $30-40$ & 42 & 23 & 13 & 26 & 11 & 6 & 1 & 1 & - & 17 & 140 \\
\hline 4050 & 8 & 3 & 4 & 12 & 3 & 6 & - & - & - & 3 & 39 \\
\hline $50-60$ & 1 & - & - & 3 & 1 & - & - & - & - & . & 5 \\
\hline $60-70$ & 1 & 1 & - & 7 & - & - & & - & & - & 9 \\
\hline $70-80$ & - & - & - & 2 & - & - & - & - & & - & 2 \\
\hline $80-90$ & - & 1 & - & 4 & - & - & - & - & - & - & 5 \\
\hline F. 3 & . & 1 & - & - & 3 & I & 1 & 1 & - & - & 7 \\
\hline F. 4 & 2 & - & 1 & - & - & - & 1 & - & 1 & & 5 \\
\hline F. 7 & 2 & . & 1 & - & . & - & & - & - & & 3 \\
\hline
\end{tabular}

*B=brushed; $\mathrm{P}=$ punctated; $\overline{\mathrm{l}=\text { incised; }} \overline{\mathrm{F}}=$ engraved; $\mathrm{B} / \mathrm{P}=\mathrm{b}$ rushed/punctated; $\quad \mathrm{B} / \mathrm{P} / \mathrm{R}=\mathrm{b}$ rushed/punctated/ridged; $\mathrm{P} / \mathrm{R}=$ punctated/ridged; $\mathrm{RS}=$ rcxl-slipped; $\mathrm{PR}=$ plain $\mathrm{rm}$

The majority of the brushed sherds (62 percent) have random (probably vertical brushing on the body) brush marks (Figure 5a). Another 26 sherds (15.7 percent) have parallel brushed marks that intersect, and 25 sherds appear to have been brushed with a fine comb. On a few sherds (1.8 percent), the brushing marks may have been smoothed after the body was initially brushed. 


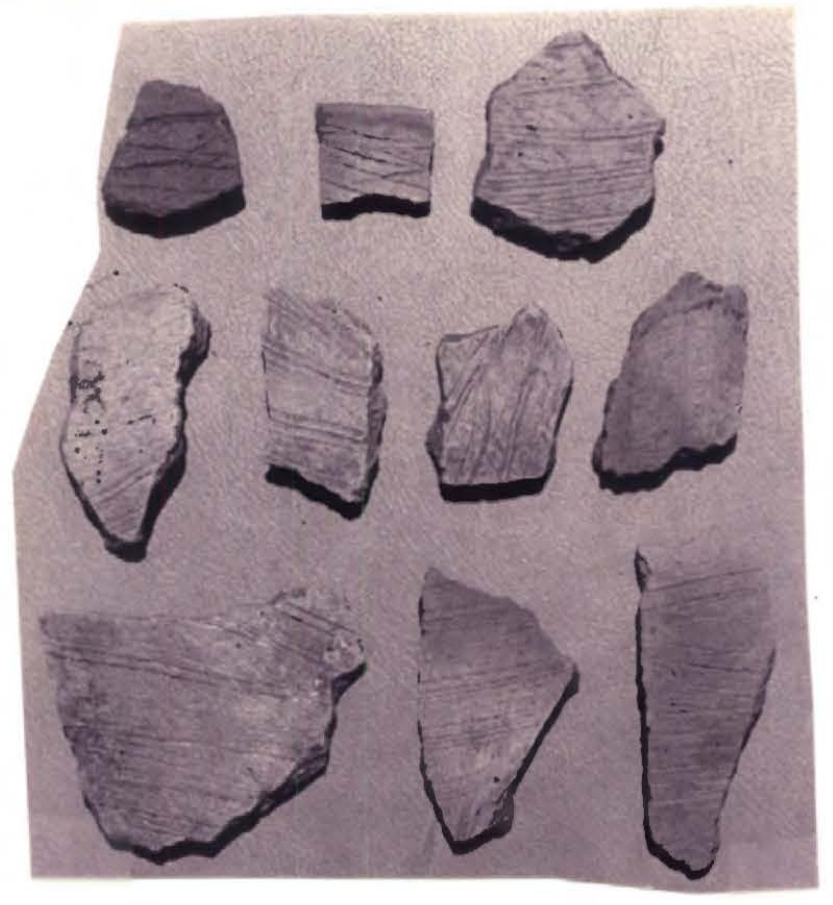

A

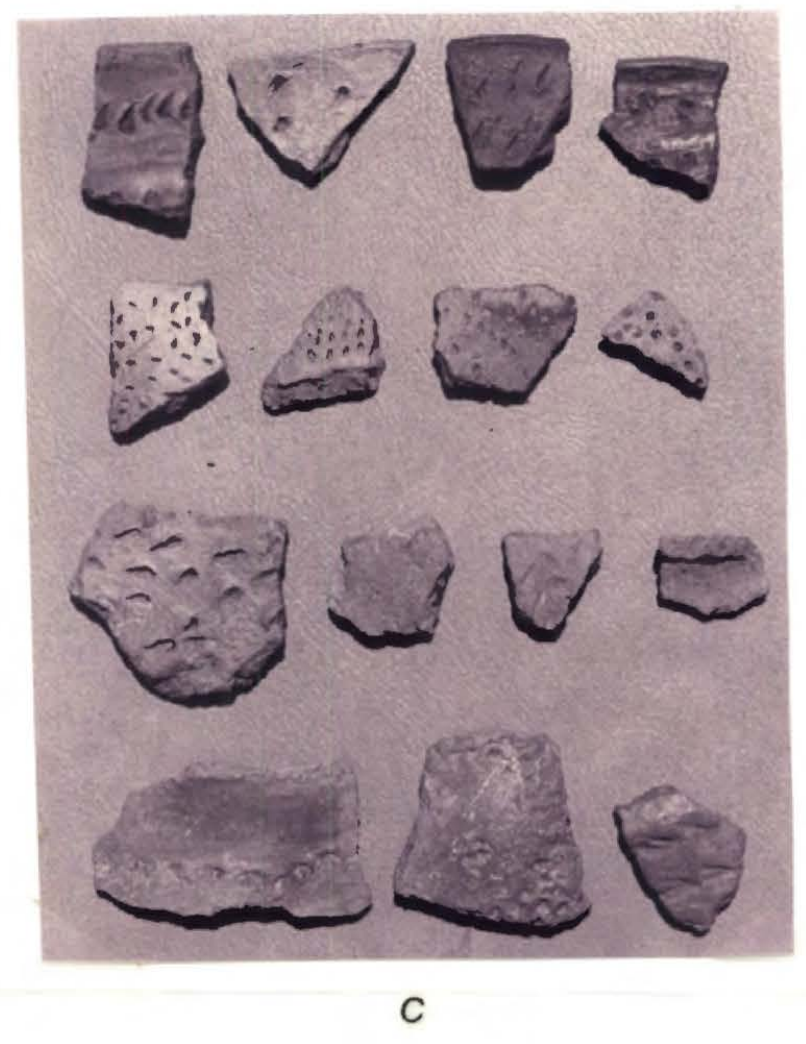

Figure 5. Decorated Sherds: a, brushed; b, engraved; c, punctated; d, incised. 
There is a wide variety of design elements among the engraved sherds in the Redwine ceramic assemblage (Figure 5b). About 21 percent of the engraved sherds have opposing lines or intersecting lines, and 13.4 percent have a concentric design element.

About 12 percent of the engraved sherds have either parallel, concentric, or circular parallel lines filled with closely-spaced cross-hatching (see Figure 5b). Virtually identical design elements are notable in the engraved sherds from the Middle Caddoan Oak Hill village site, and the engraved lines are commonly filled with a red pigment.

Horizontal parallel engraved lines comprise 7.4 percent, while 3 percent have vertical parallel lines or ladders. Five sherds have what we refer to as a "brick wall" design element, consisting of closely spaced and intersecting vertical and horizontal engraved lines; a carinated bowl with this design element was also found as a grave good in Burial 1 .

Rare engraved elements include one with diagonal lines, and one with pendant triangles placed between parallel horizontal lines. One bottle sherd has parallel (probably verticallyoriented) lines that separate panels filled with engraved boxes, triangles, and ladders, and another has parallel vertical lines filled with diagonal lines between them (this motif resembles a bottle section found in the mound excavations; see below). Finally, 36 percent of the engraved sherds simply have one or more straight lines, but no discernible design element.

Among the punctated sherds, the design element primarily consists of randomly placed body punctations (Figure $5 \mathrm{c}$ ) done with a fingernail $(n=12)$, a tool $(n=23)$, or possibly a round piece of cane $(n=19)$. Another 31 punctated sherds have gouge marks. Rows of fingernail or tool punctates comprise only 15.8 percent of the sample, and there are 10 sherds with a single straight line of tool punctates. One sherd has V-shaped punctates, and is perhaps related to the ridged-pinched category.

Unidentified elements of single line $(n=32)$ and parallel line $(n=22)$ incised sherds are well represented at Redwine, along with cross-hatched incised $(n=18)$ rim and body sherds (Figure 5d). Ten percent of the incised sherds have diagonal or opposing sets of lines.

The most common design elements among the incised-punctated sherds are triangular panels of incised lines filled with punctates $(n=17)$ and curvilinear incised lines filled with punctates ( $\mathrm{n}=11$; Figure 6a); the latter resembles Crockett Curvilinear Incised, but is probably a local later version similar to a number of vessels documented at the Washington Square Mound site (cf. Corbin and Hart 1998:Figure 5). Two other sherds have incised rectangular box designs filled with punctates. The remainder of the incised-punctated sherds (29 percent) consist of an incised line or lines separated by a row of punctates (either fingernail or tool punctates).

The majority of the brushed-punctated sherds ( $\mathrm{n}=25$ or 78 percent) have parallel brushing with randomly placed punctations (Figure $6 \mathrm{~b}$ ). Four sherds have brushed marks with rows of tool punctates, and three others have horizontal brushing and rows of punctations on the rim (see Figure 6b); these may be from Pease Brushed-Incised jars.

The eight pinched-ridged sherds (Figure $6 \mathrm{c}$ ) were decorated by using a tool or a fingernail to push up parallel coils of clay. At least one pinched-ridged body sherd is from a Killough Pinched vessel, and Killough Pinched jars were found among the grave goods in both Burial 1 and Burial 2 (see below). 


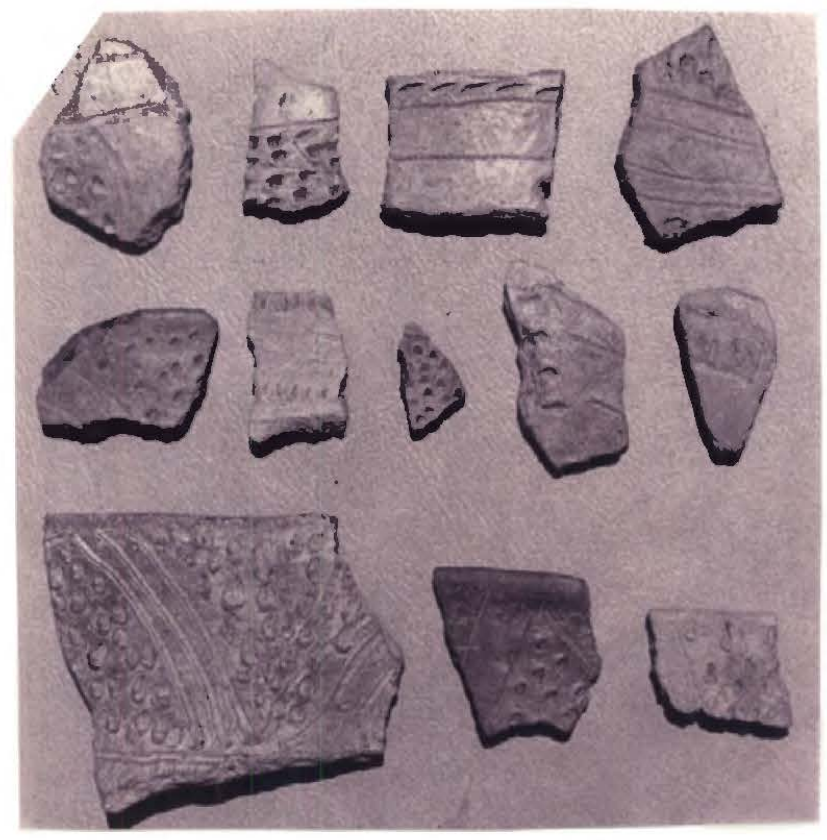

A

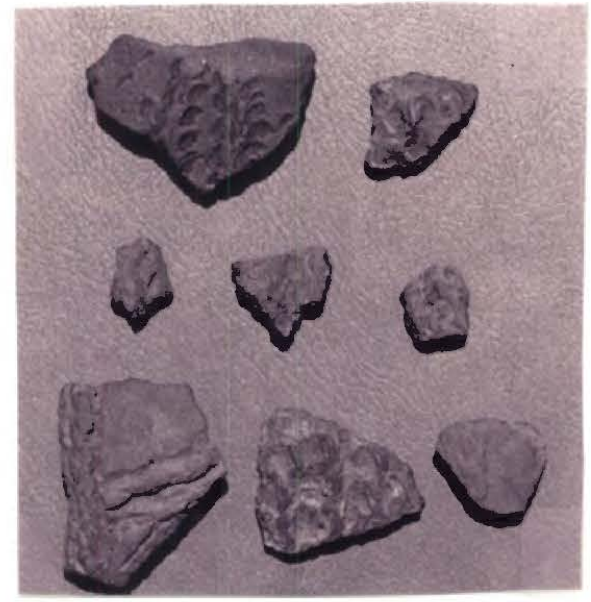

C

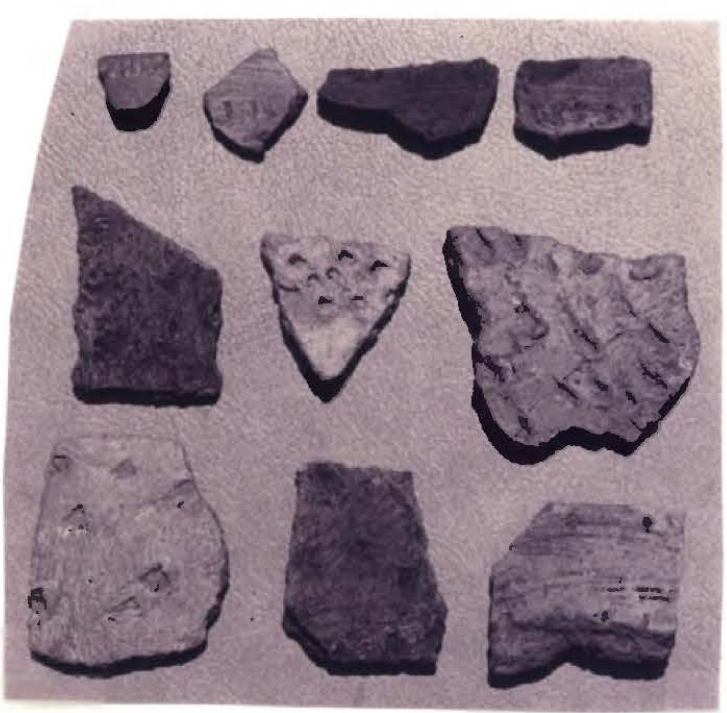

$B$
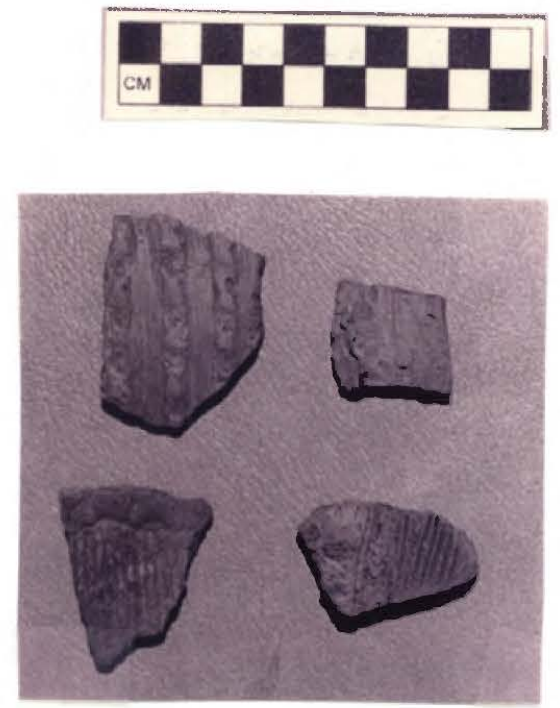

$D$

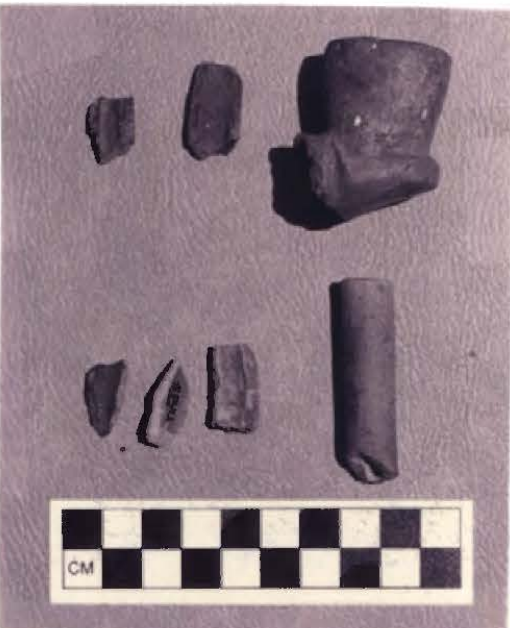

$E$

Figure 6. Decorated Sherds and Pipes: a, incised-punctated; b, brushed-punctated; $c$, pinched-ridged; brushedpinched-ridged; e, pipe sherds. Note elbow pipe in upper right. 
The four brushed-pinched-ridged sherds appear to be from the body of Pease BrushedIncised jars. The pinched-ridged element on these sherds are separated by brushed panels (Figure 6d).

There are three plain red-slipped body sherds in the decorated assemblage from Redwine. One of the plain inverted rim sherds may also have a red slip on its exterior surface.

Most of the plain rim sherds were everted with flat lips $(n=35)$, with another 30 percent were straight with rounded lips. One of the straight rims has a scalloped lip, and one everted rim has a crenelated or pie-crust lip. Inverted rims comprise 10.8 percent of the plain rim sample, and three other sherds have rim peaks.

The Redwine sherds are tempered with bone/grog, bone/grog/grit, grog, grit, and grog/grit; some of the grit consisted of crushed hematite. Of the decorated body sherds, 47 percent contained some amount of bone tempering (Table 4), and 51 percent of the rim sherds also had bone tempering. The frequency of bone temper was slightly lower (42.8 percent) among the body sherds, but nevertheless, the frequency of bone tempering in the Redwine sherds is notable.

Table 4. Ceramic Temper Analysis

\begin{tabular}{llll}
\hline Type & Total & Bone* & Grog/Grit** \\
\hline Decorated Body & 523 & $47.0 \%$ & $53.0 \%$ \\
Rim Sherds & 139 & $51.1 \%$ & $48.9 \%$ \\
Plain Body Sherds & 1339 & $42.8 \%$ & $57.2 \%$ \\
\hline
\end{tabular}

* 1ncludes bone, bone/grog, and bone/grog/grit

** Includes grog, grog/grit, and grit

Sherd thickness ranges from 4.2-12.8 mm, with an average sherd thickness of $7.3 \mathrm{~mm}$. Bone/grog-tempered sherds have a mean thickness of $7.03 \mathrm{~mm}$; bone/grog/grit-tempered sherds are $7.53 \mathrm{~mm}$ in mean thickness; grog-tempered sherds are $7.1 \mathrm{~mm}$ in mean thickness; and the mean thickness of grog/grit-tempered sherds is $7.53 \mathrm{~mm}$.

\section{Pipe Sherds}

Six of the seven ceramic pipe sherds are from long-stem Red River style pipes (see Figure 6e), common until ca. A.D. 1400 in Caddoan sites in Northeast Texas. Four of the stem fragments were found in the surface collection, and the other two in the plow zone excavations. The other, tempered with grog and bone, was a $27 \mathrm{~mm}$ diameter bowl from a distinctive flat-based elbow pipe with carved indentations on each side of the stem (see Figure 6e). This bowl was recovered in the midden deposits (another was found with one of the Redwine burials; see below). Similar flat-based elbow pipes have been recovered in ca. A.D. 1300- 1400 contexts at the Oak Hill village site in Rusk County, Texas.

\section{Lithic Artifacts}

Lithic artifacts from Redwine included 122 flakes, two cores, 10 fire-cracked rocks, seven pieces of groundstone (including two abraders; Figure 7d), three celt fragments (Figure 


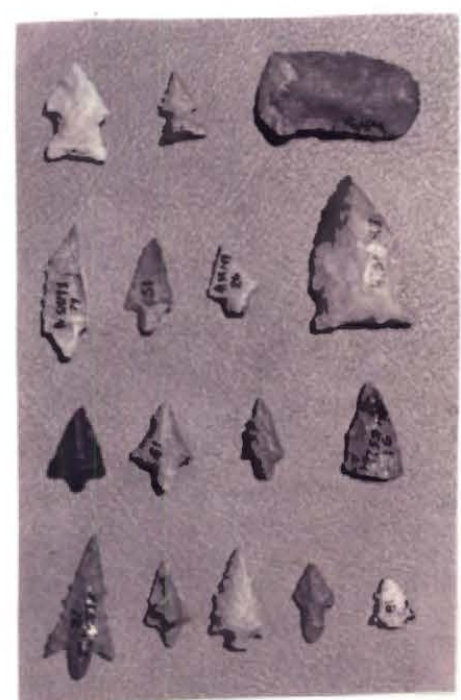

$A$

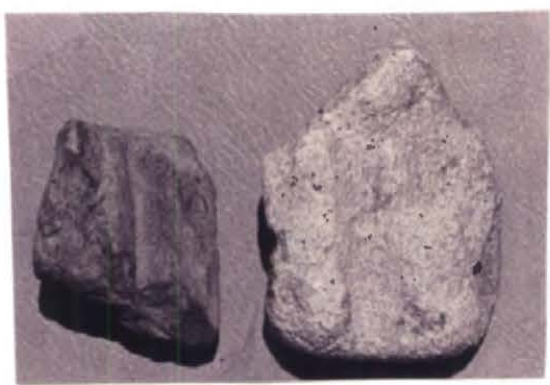

$D$

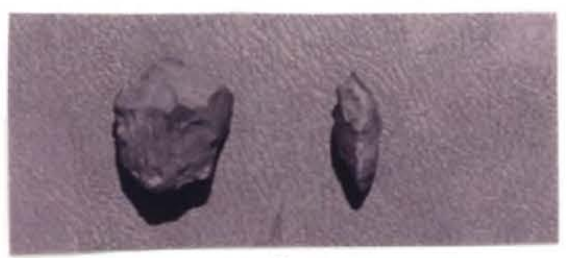

$B$

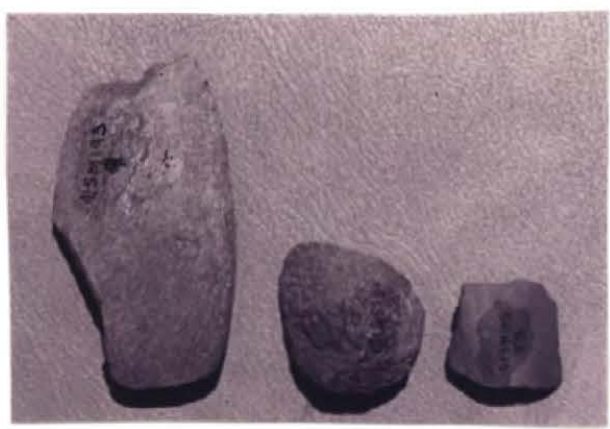

C

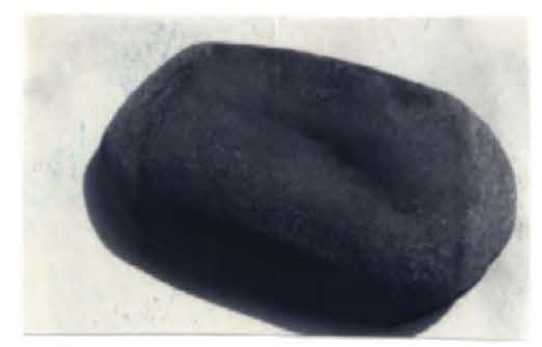

E

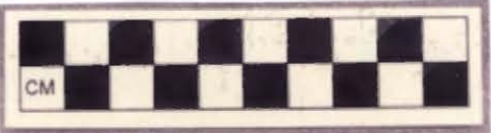

Figure 7. Lithic Artifacts: a, projectile points and scraper; b, cores; c, celt fragments; d, abraders; e, hammerstone. 
7c), one hammerstone (Figure 7e), one end scraper (Figure 7a), one dart point, and 14 arrowpoints. The low density of lithic artifacts suggests that wood (and bone) tools were probably important parts of the material culture of this Middle Caddoan group. Information on the complete arrow points from the site is provided in Table 5 .

\section{Table 5. Projectile Points}

\begin{tabular}{lllll}
\hline Lot & Type & Length $(\mathrm{mm})$ & Width $(\mathrm{mm})$ & Thickness $(\mathrm{mm})$ \\
\cline { 3 - 4 } 12 & & & & -1 \\
23 & Perdiz & 32.0 & 16.0 & 3.2 \\
26 & Perdiz & 18.5 & 12.4 & 5.4 \\
36 & Perdiz & 16.7 & 12.5 & 3.8 \\
45 & $?$ & 17.8 & 9.5 & 3.0 \\
51 & $?$ & 15.9 & 10.9 & 3.1 \\
58 & Perdiz & 21.8 & 12.3 & 4.3 \\
66 & $?$ & 21.3 & 14.8 & 6.3 \\
79 & Perdiz & 18.3 & 9.3 & 4.1 \\
& Perdiz & 29.4 & 11.0 & 3.8 \\
\hline
\end{tabular}

The lithic debris is primarily Ogallala quartzite, along with two petrified wood flakes; 20 of the pieces of debris are bifacial thinning flakes. The two cores are small $(3-4 \mathrm{~cm}$ in length and width) (see Figure 7b), with little available raw material for tool manufacture. The hammerstone is made of quartzite, and has battered at both ends of the $10 \times 6 \mathrm{~cm}$ cobble. The end scraper (from the surface collection) is unifacial, and the flake has cortex on one side of the piece.

Eleven of the 14 arrowpoints are of the Perdiz type (three from the surface and the others from the midden and pit features) (Figure 7a). At least three of the Perdiz arrowpoints were made from unifacially worked flakes, and another three were thick and probably heavily reworked. They range in size from 15.9-32.0 $\mathrm{mm}$ in length, 9.3-14.8 $\mathrm{mm}$ in width, and 3.0-6.3 mm in thickness. The Perdiz specimens were manufactured from black, brown, and grayish-tan chert as well as Ogallala quartzite. Two other arrowpoints are extensively resharpened Scallorn specimens (both found on the surface), and the final arrowpoint is a tip recovered during the surface collection. The one dart point (an Ensor) was recovered on the surface during the controlled surface collection (see Figure 7a).

The hammerstones, small cobble cores, and lithic debris indicate that lithic tools were manufactured on the site, probably from very small cobbles of Ogallala quartzite; there are no known sources of workable lithic raw materials within $25 \mathrm{~km}$ of the Redwine site.

\section{Summary of the Subsistence Information}

One of the main purposes for investigating the Redwine site was to gather information about the Caddoan peoples who lived there and how their subsistence practices compared to other similar Northeast Texas Caddoan sites. Faunal and floral remains were collected from the screening of soil through 1/4-inch mesh and from several flotation samples (from a $10 \mathrm{~cm}$ square in Unit 1, and Feature 3). The flotation samples were processed by Coastal Environments, Inc. of Baton Rouge, Louisiana. David H. Jurney (1996) completed the analysis of the faunal remains, while Eileen Goldborer (1997) analyzed the charred plant remains. 
Our findings suggest that the Caddoan subsistence at Redwine during the Middle Caddoan period was based on hunting/gathering of wild plants and animals and the cultivation of maize. This is comparable to other Middle to Late Caddoan sites in Northeast Texas.

\section{Faunal Analysis, by David H. Jurney}

The sample of Redwine fauna examined for this study consists of 1353 bone fragments, including teeth, antler, and shell, from 38 individual lot designations (Table 6); the remainder of the faunal assemblage, some 500 elements, remains to be analyzed. Much of the bone was burned (64 percent) and unidentified ( 90 percent), and included small mammal $(n=3)$, medium mammal $(n=7)$, and large mammal $(n=1209)$ size classes. Ten species or taxa were identified, including mussel $(n=1)$, fish $(n=1)$, turtle $(n=1)$, wild turkey $(n=8)$, duck $(n=1)$, rabbit $(n=13)$, raccoon $(n=6)$, canid? $(n=1)$, and deer $(n=99)$. Deer comprised 74.4 percent of the identified bone, with a minimum of three individuals (based on tooth eruption and epiphyseal union): a juvenile (0.5-1.0 year old, fall/winter), an adult male (shed antler, spring), and a sub-adult. Rabbit amounted to 9.7 percent of the identified bone, followed by turkey (6.1 percent) and raccoon $(4.5$ percent). Deer and turkey bones were widely dispersed across the excavations, being recovered from 15-48.8 percent of the lot proveniences.

A small amount of freshwater mussel shell was present in the midden deposits, including an example of Tritogonia verrucosa from Feature 7 and a Fusonaia sp. from N445E505, $30-40 \mathrm{~cm}$ bs (Jesse Todd, 1996 personal communication to Mark Walters). Both species occur widely in East Texas streams, both large and small (Cheatum and Flook 1974; Howells et al. 1996).

Based on seasonal indicators, the Redwine site was occupied from fall to spring. A full range of deer age classes was hunted, and the carcasses were returned to the site. Some butchering evidence indicated disarticulation of the deer. The high frequency of split and unidentified large mammal bone is probably due to the beating, hacking, and boiling of pieces of meat. 'The high frequency of burning indicates either the burning of food waste or the preparation of tempering for ceramic manufacturing. Among the species, 39.3 percent of the deer bone was burned; 53.8 percent of the rabbit bone; 33 percent of the raccoon, and 25 percent of the wild turkey bone. Dog and rodent gnawing on some of the bones indicates post-depositional modifications by scavenging fauna.

\section{Floral Analysis, by S. Eileen Goldborer}

Six flotation samples have been analyzed by Goldborer (1997) from the Redwine site, five from Feature 3 and a sixth sample from Unit 1 . Three of the samples from Feature 3, level 2 have been combined for the purpose of reporting. Light and heavy fractions for all samples are analyzed and tabulated separately, and the results of the analyses are provided in Table 7. 
Table 6. Faunal Remains from the Redwine Site.

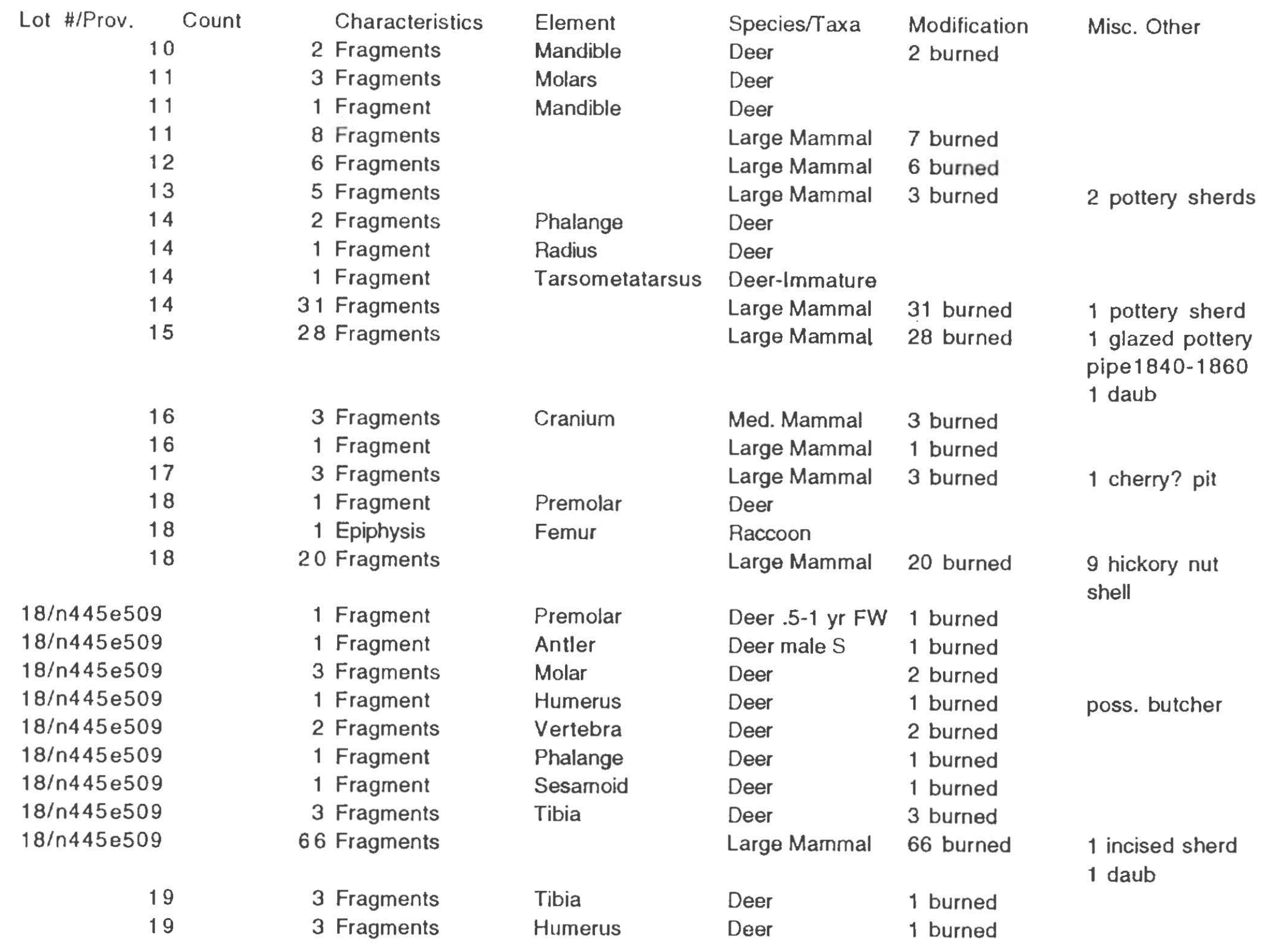


Table 6, cont.

\begin{tabular}{|c|c|c|c|c|c|}
\hline 19 & 1 Fragment & Radius & Deer & 1 burned & \\
\hline 19 & 1 Fragment & Phalange & Deer & 1 burned & \\
\hline 19 & 2 Fragments & Femur & Raccoon & & \\
\hline 19 & 1 Fragment & Femur & Wild Turkey & & \\
\hline 19 & 128 Fragments & & Large Mammal & 128 burned & 1 sherd, 1 flake \\
\hline 20 & 1 Fragment & Molar & Deer & & \\
\hline 20 & 1 Fragment & Tibia & Raccoon & 1 burned & \\
\hline 20 & 1 Fragment & Femur & Wild Turkey & 1 burned & \\
\hline 20 & 1 Fragment & Radius & Med. Mammal & 1 burned & \\
\hline 20 & 1 Fragment & Tarsometatarsus & Med. Mammal & 1 burned & \\
\hline 20 & 67 Fragments & & Large Mammal & 67 burned & 3 daub \\
\hline 21 & 2 Fragments & Tibia & Deer & & \\
\hline 21 & 1 Fragment & Rib & Deer & Rodent gnawed & \\
\hline 21 & 1 Fragment & Phalange & Deer & & \\
\hline 21 & 1 Fragment & Tibia & Raccoon & 1 burned & \\
\hline 21 & 1 Fragment & Podial & Raccoon & & \\
\hline 21 & 1 Fragment & Rib & Wild Turkey & & \\
\hline 21 & 120 Fragments & & Large Mammal & 60 burned & 1 rim sherd \\
\hline 22/445E507H & 8 Fragments & Femur & Deer & 1 dog gnawed & \\
\hline $22 / 445 E 507 \mathrm{H}$ & 2 Fragments & Humerus & Deer & & \\
\hline 22/445E507H & 1 Fragment & Th. Vertebra & Deer & & \\
\hline $22 / 445 E 507 \mathrm{H}$ & 3 Fragments & Scapula & Deer & & \\
\hline $22 / 445 \mathrm{E} 507 \mathrm{H}$ & 1 Fragment & Phalange & Deer & & \\
\hline $22 / 445 \mathrm{E} 507 \mathrm{H}$ & 3 Fragments & Rib & Deer & & \\
\hline 22/445E507H & 63 Fragments & & Large Mammal & 15 burned & \\
\hline 23 & 2 Fragments & & Large Mammal & 1 burned & \\
\hline 24 & 23 Fragments & & Large Mammal & 23 burned & $\begin{array}{l}10 \text { hickory nut } \\
\text { shell, } 2 \text { wood } \\
\text { charcoal }\end{array}$ \\
\hline 25 & 1 & Radius & Deer & 14 pieces/exc. & \\
\hline 26 & 5 Fragments & & Large Mammal & 5 burned & \\
\hline 27 & 1 & Phalange & Deer & & \\
\hline 27 & 3 Fragments & & Large Mammal & & \\
\hline
\end{tabular}


Table 6, cont.

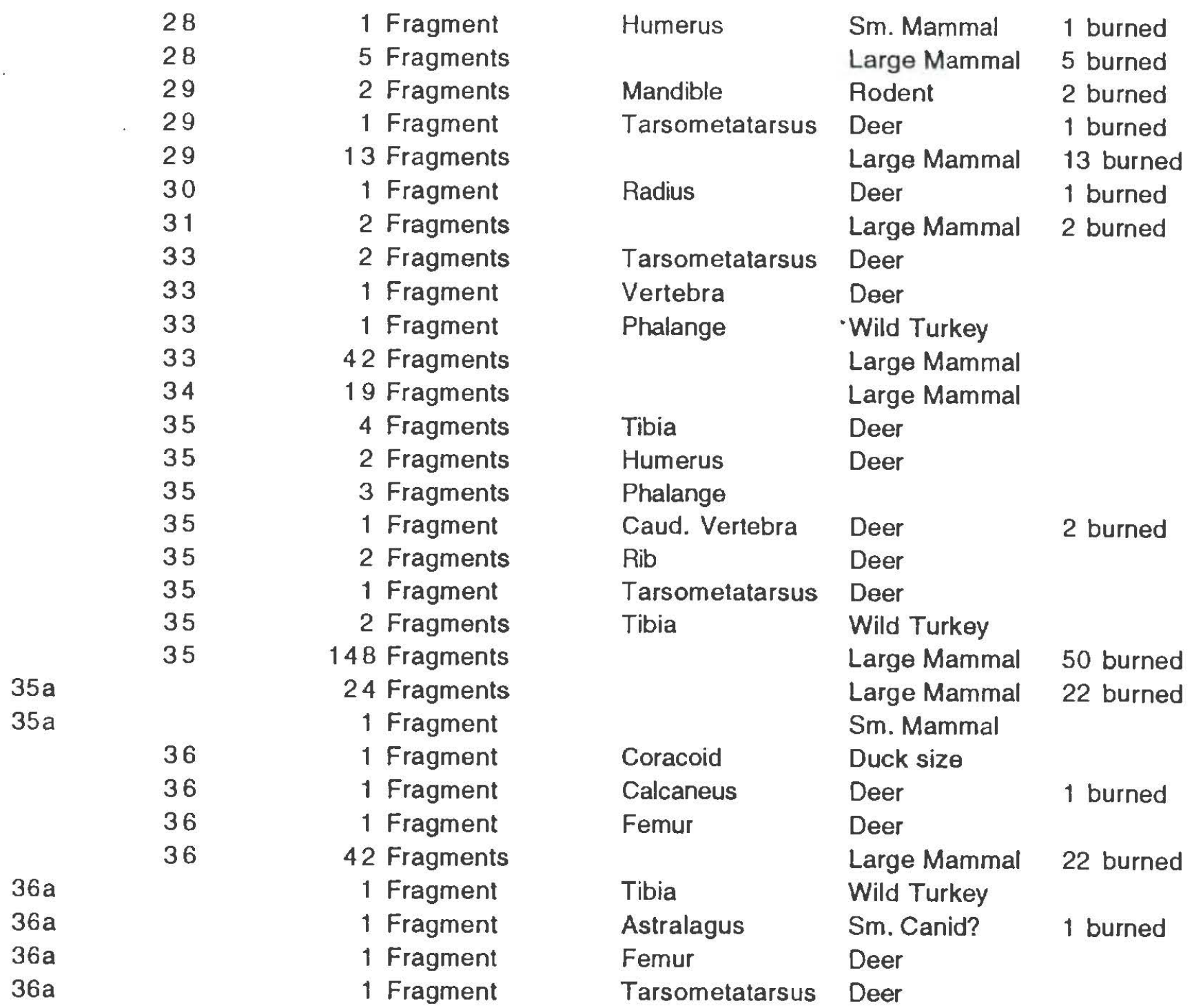


Table 6, cont.

$36 a$

$36 a$

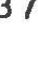

38
1 Fragment 62 Fragments

1 Fragment

2 Fragments

1 Fragment

32 Fragments

1 Fragment

1 Fragment

1 Fragment

18 Fragments

3 Fragments

1 Fragment

2 Fragments

1 Fragment

1 Fragment

78 Fragments

24 Fragments

1 Fragment

12 Fragments

13 Fragments

3 Fragments

1 Fragment

1 Fragment

1 Fragment

1 Fragment

1

5 Fragments
Sm. Mammal

Large Mammal 12 burned

Phalange Deer

$\begin{array}{lll}\text { Rib } & \text { Deer } & 1 \text { burned } \\ \text { Femur } & \begin{array}{l}\text { Deer } \\ \text { Large Mammal }\end{array} & 9 \text { burned } \\ \text { Mandible } & \text { Rabbit } & \\ \text { Femur } & \text { Rabbit } & \\ \text { Humerus } & \text { Deer } & 1 \text { burned } \\ & \text { Large Mammal } & 8 \text { burned } \\ & \text { Large Mammal } & 3 \text { burned } \\ \text { Tibia } & \text { Deer } & 1 \text { burned } \\ \text { Phalange } & \text { Deer } & 2 \text { burned } \\ \text { Humerus } & \text { Deer } & 1 \text { burned } \\ \text { Femur } & \text { Deer } & 1 \text { burned } \\ & \text { Large Mammal } & 78 \text { burned } \\ & \text { Large Mammal } & 24 \text { burned } \\ \text { Coracoid } & \text { Wild Turkey } & 1 \text { burned } \\ & \text { Large Mammal } & 2 \text { burned } \\ & \text { Large Mammal } & 6 \text { burned } \\ & \text { Large Mammal } & 3 \text { burned } \\ \text { Carapace } & \text { Turtle } & \\ & \text { Mussel } & 1 \text { burned } \\ \text { Cranial } & \text { Fish } & \\ \text { Incisor } & \text { Rabbit } & 1 \text { burned } \\ \text { Scapula } & \text { Rabbit } & 5 \text { burned } \\ \text { Humerus } & \text { Rabbit } & \end{array}$


Table 6, cont.

$\begin{array}{lr}\text { 45/F7 } & 3 \text { Fragments } \\ \text { 45/F7 } & 1 \text { Fragment } \\ 45 / F 7 & 2 \text { Fragments } \\ 45 / F 7 & 2 \text { Fragments } \\ \text { 45/F7 } & 2 \text { Fragment } \\ 45 / F 7 & 1 \text { Fragments } \\ 45 / F 7 & 2 \text { Fragme } \\ 45 / F 7 & 1 \text { Fragment } \\ 45 / F 7 & 1 \text { Fragment } \\ \text { 45/F7 } & 2 \text { Fragments } \\ \text { 45/F7 } & 90 \text { Fragments } \\ \text { Total } & 1353\end{array}$

$\begin{array}{lll}\text { Scapula } & \text { Rabbit } & \\ \text { Cranium } & \text { Rabbit } & 1 \text { burned } \\ & \text { Med. Mammal } & 2 \text { burned } \\ \text { Phalange } & \text { Deer } & 1 \text { burned } \\ \text { Phalange } & \text { Deer } & 1 \text { burned } \\ \text { Vertebra } & \text { Deer } & 1 \text { burned } \\ \text { Rib } & \text { Deer } & 2 \text { burned } \\ \text { Radius } & \text { Deer } & 1 \text { burned } \\ \text { Tarsometatarsus } & \text { Deer } & 1 \text { burned } \\ \text { Tibia } & \text { Deer } & 2 \text { burned } \\ & \text { Large Mammal } & 82 \text { burned } \\ & & 867 \text { burned }\end{array}$


Table 7. Carbonized Plant Remains from Redwine (41SM193)

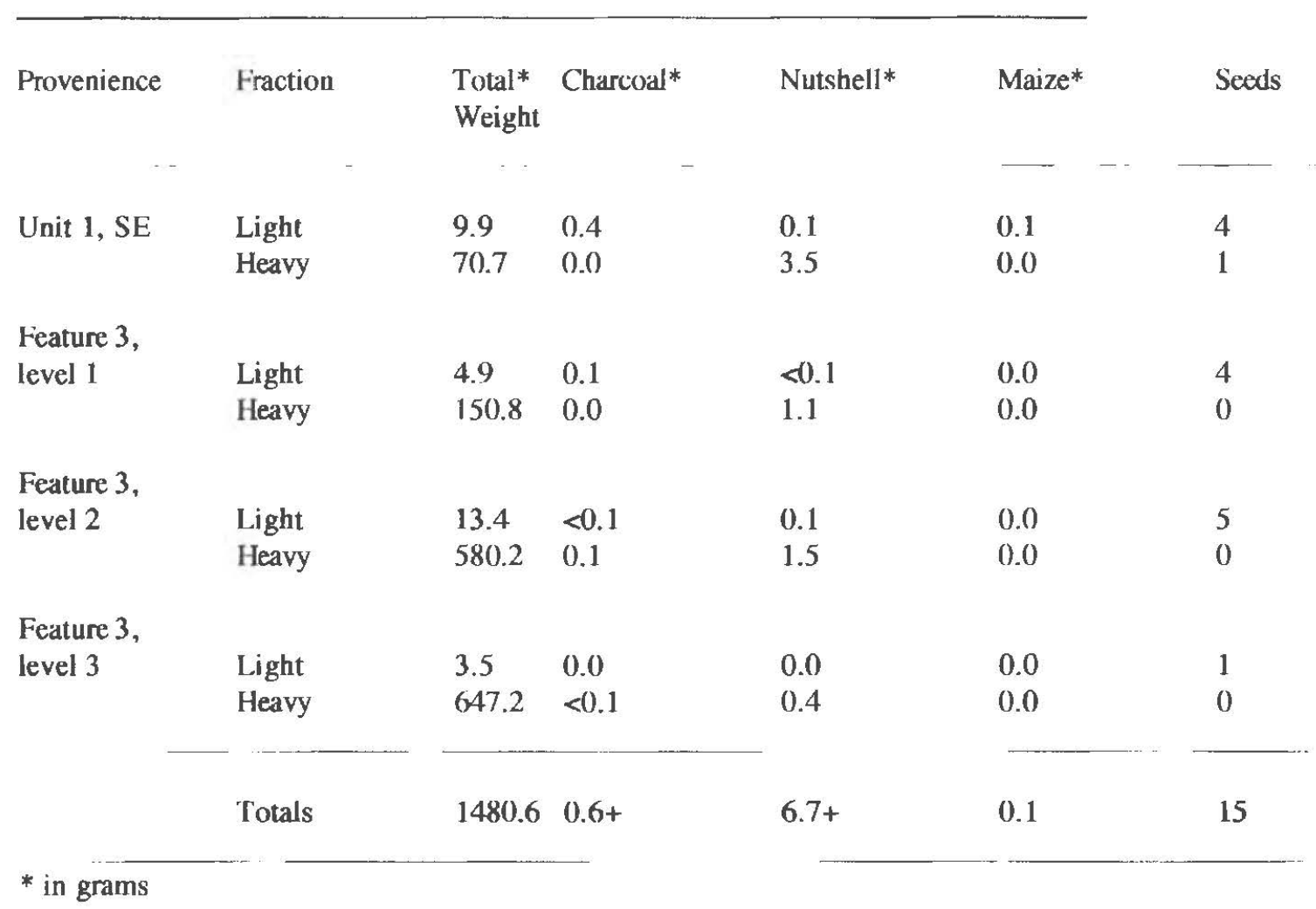

Charred and uncharred materials were sorted from the soil matrix. Carbonized remains include wood charcoal, hickory nutshell, sumac, wild grape seeds, and maize (see Table 7). All the samples also had uncharred seeds $(n=284)$, especially carpetweed (Mollugo sp.) and flatsedge (Cyperus sp.), but including 15 different species (Goldborer 1997:Table 2). Uncharred seeds are considered modern contaminants (Minnis 1981:143-150).

Both light and heavy fractions were weighed before sorting, and then each sample was passed through geological sieves $(4.0,2.0,1.0$, and $0.5 \mathrm{~mm})$. All fractions were fully sorted except for charcoal and nutshell pieces below $2 \mathrm{~mm}$ in size. All charred seeds and maize were removed for analysis. The fractions were sorted under a binocular microscope (7-45X power), and standard identification manuals (Delorit 1970; Martin and Barkley 1973; Montgomery 1977) and a comparative collection were used to identify seeds. A comparative collection and standards references (Core et al. 1979; Dimbleby 1967) were used to identify wood specimens.

All samples had wood charcoal above $2 \mathrm{~mm}$ in size, but the amounts were extremely small (see Table 7). Two charred fragments of oak were identified in Feature 3, level 2.

Nutshell was present in amounts ranging from 0.3-3.6 g per sample. All the nutshell was hickory.

Only the light fraction of the Unit 1 flotation sample contained maize. Two relatively whole maize cupules and two cupule fragments were present, weighing less than $0.1 \mathrm{~g}$. Although part of a wing has been lost, approximately 95 percent of the larger cupule's (Cupule A) width has been preserved. The remaining portion is $4.2 \mathrm{~mm}$ wide, suggesting an unbroken size of about $4.4 \mathrm{~mm}$. The internode length of that cupule is $3 \mathrm{~mm}$. Approximately 90 percent of another cupule (Cupule B) has also been preserved. That cupule has a remaining 
width of $4 \mathrm{~mm}$, suggesting an original charred width of about $4.3 \mathrm{~mm}$. It has a relatively short wing, producing a length of $0.6 \mathrm{~mm}$. One other cupule fragment includes part of the mid-section and one wing. The preserved portion, probably representing about 55 percent of its charred width, is $3.5 \mathrm{~mm}$, suggesting an original uncharred width of ca. $6.5 \mathrm{~mm}$. A second fragment, with both wings eroded, has a remaining width of $3.3 \mathrm{~mm}$. Its length is $1.5 \mathrm{~mm}$.

Charred seeds are present in each of the samples (see Table 7). There are 12 sumac seeds in three samples. Size and configuration of the seeds indicate either Rhus copallina or $R$. glabra, both still present in Northeast Texas (Vines 1982:302-308). Two wild grape seeds occur in two fractions (Unit 1 and Feature 3, level 1).

The general plant assemblage reported from Middle to Late Caddoan sites includes both domestic and wild plants (Fritz 1992; Goldborer 1995; Perttula et al. 1982). The botanical remains from the four Redwine flotation samples reflect the same sort of general assemblage: maize, hickory nutshell, and the charred grape and sumac seeds could have been food resources.

Various ethnographic accounts of eastern North American Indian groups mention the crushing of hickory nutshell to gather the nutmeat and its oil (Bartram 1791:38; Harris 1937:165). Hickory nuts and corn can both be stored for long periods, so that their presence does not necessarily reflect a particular season of availability. On the other hand, the presence of grape and sumac probably does represent a seasonal consumption. The fruit of wild grape species in East Texas ripen at various times from August to November (Correll and Johnston 1979:1017-1021). The availability of the sumac drupes overlap that of wild grape from August to October (Elias 1980:803-805). The malic acid in the acrid drupes provides a lemonade-like beverage when crushed and steeped in warm water (Vines 1982:306; Tull 1987:35).

The plant remains at Redwine indicate a combined use of domestic and wild resources, as noted at the Steck site (41WD529), a Late Caddoan site in adjoining Wood County (Perttula et al. 1982:93-95). Unfortunately, the few maize cupules in the Redwine flotation samples do not provide a picture of what the reliance on maize was at the time. However, the two whole cupules and two fragments do give us some morphological information on the maize that was used there. The proportions suggest that the maize was the same small, probably 8-rowed, corn observed by Goldborer in samples from other Northeast Texas sites, including Ray (41LR135), Roitsch (41RR16), and 41UR118. Others have also described similar maize from sites in the region (Fritz 1992; Jones 1949). These morphological proportions are smaller than documented for many areas of eastern North America, and are noted for both the Early to Late Caddoan period.

The Redwine flotation samples, although few in number, do further supplement the growing botanical data base for Northeast Texas. Although reliance levels cannot be established for the plant foods, subsistence appears to have included both domestic and wild plant resources at this Middle Caddoan site. The morphological information from maize cupules at Redwine supports the presence of a small 8-rowed corn within this part of the Caddoan area.

\section{Mound Excavations, by Timothy K. Perttula}

The Redwine site had a single, low earthen mound built during Middle Caddoan times. The mound was located in the northwestern part of the site, on the highest elevation of the landform, with extensive habitation debris to the south and east along the ridge (see Figure 
1). The mound was excavated using a small tractor and slip to remove the mound fill to depths of between 1.0 feet ( 0.31 meters) and 2.5 feet ( 0.73 meters) over an area of 375 square feet (34.65 square meters), and then shovel and trowel were employed to expose postholes and other features below the mound.

From the available notes and records made by Sam Whiteside, it appears that the mound was approximately 2.5 feet $(0.73$ meters $)$ in height and 24 feet $(7.3$ meters $)$ in diameter. The mound was constructed in one episode, with a sandy loam mound fill placed over a charcoal-stained soil associated with the construction, use, and destruction of a circular structure (Figure 8); the charcoal-stained sand immediately below the mound suggests that the structure had been burned prior to its being covered by the sandy loam mound fill.

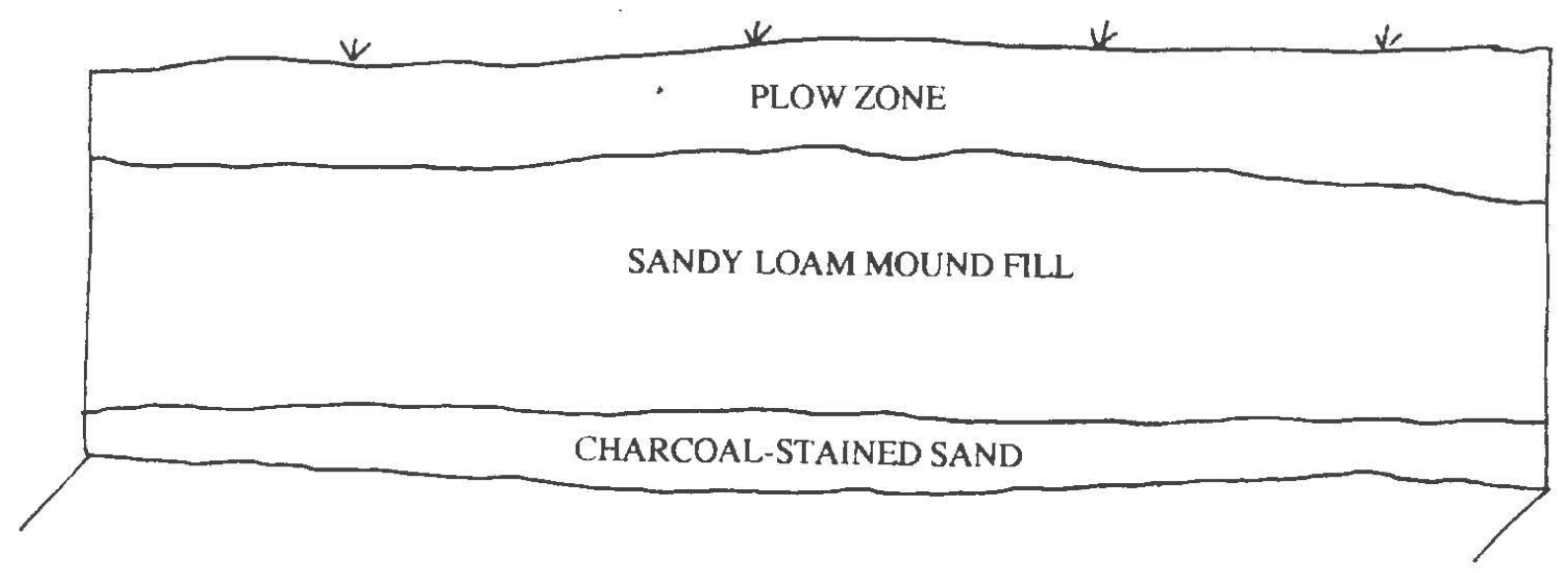

Figure 8. Profile of the Mound Excavations.

The partially exposed circular structure below the mound was marked by 23 regularlyspaced wail posts and three posts marking the extended entranceway; the entranceway faced southeast towards the main part of the site (Figure 9). The estimated diameter of the circular structure is approximately 5.5 meters, and the short entranceway extends only ca. 1.2 meters from the structure wall. The postholes ranged from ca. $18-25 \mathrm{~cm}$ in diameter. The lack of postholes in the southern and western part of the structure are probably the result of the fact that those portions of the structure area was only excavated to 1.0 foot below surface (bs)--not penetrating the mound fill--while the remainder was excavated to 2.5 feet bs.

There were no interior features exposed within the circular structure, but since a 50 square foot (4.6 square meters) area was not excavated in the central portions of the structure (see Figure 9), it is possible that a central hearth may have been associated with it. Immediately outside the structure's posthole arc, and west of the extended entranceway, was an 


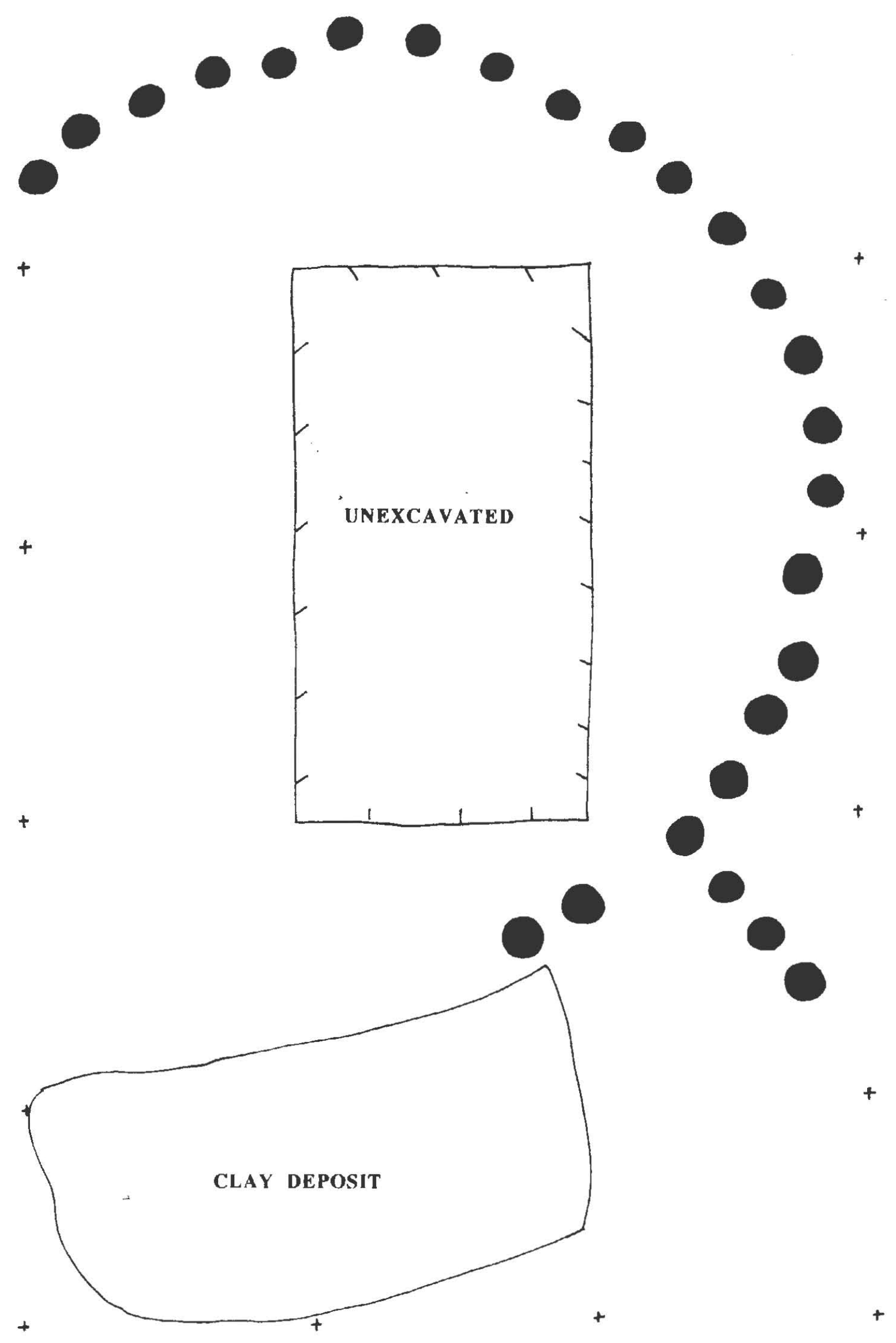

Figure 9. Plan of Circular Structure and Clay Deposit under the Redwine Site Mound. 
enigmatic deposit of clay covering about 50 square feet (4.6 square meters) (see Figure 9). No information is available on the kind of clay placed next to the structure, or its thickness, but its placement clearly suggests its function was related to the use of the special building subsequently covered by the earthen mound.

Only a single Caddoan artifact is reported from the mound excavations at Redwine. This is portions of a rectilinear engraved bottle with abundant bone temper (Figure 10).

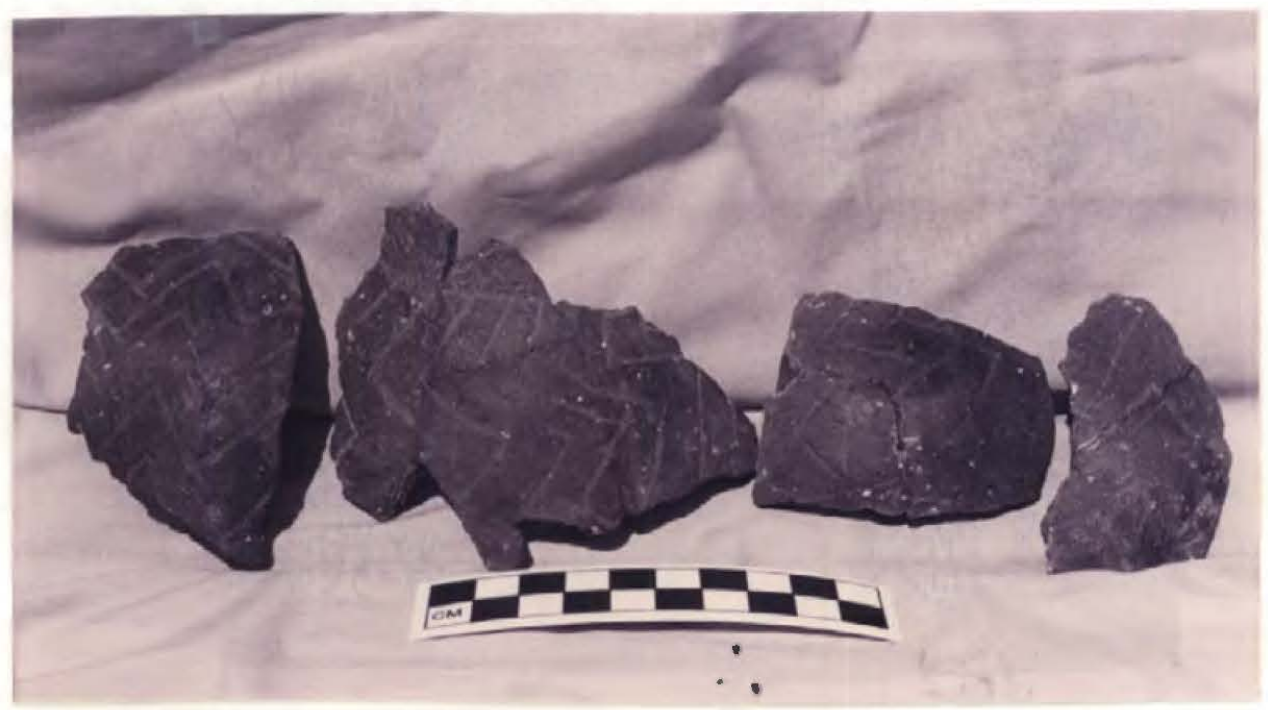

Figure 10. Engraved Bottle from Mound Excavations.

Burials and Grave Goods, by Timothy K. Perttula

Four Caddoan adult burials were excavated by Sam Whiteside at the Redwine site in the early 1960s. The exact location of these burials in relation to the house mound, or to the midden deposits excavated by Mark Walters and Patti Haskins, is unknown, and there are few details available on the burials itself. They were apparently placed in extended supine position in fairly deep (ca. 1 meter) pits, and the human remains were extremely poorly preserved, and were not recovered during the excavations.

An assortment of grave goods were placed with the burials, as follows:

\section{Burial 1}

3 ceramic jars

5 ceramic bowls

1 ceramic beaker

2 ceramic bottles

18 arrowpoints

2 ceramic pipes

\section{Burial 3}

7 ceramic bowls

1 ceramic beaker

1 ceramic bottle

1 ceramic pipe

6 arrowpoints

\section{Burial 2}

2 ceramic bowls

2 ceramic jars

\section{Burial 4}

3 ceramic bowls

1 ceramic beaker 
In total, there were 28 ceramic vessels ( 7.0 vessels per burial), three ceramic pipes $(0.75$ pipes per burial), and 24 arrowpoints (6.0 arrowpoints per burial) included as grave goods with the Redwine burials.

\section{Ceramic Vessels}

The ceramic vessels comprise 11 carinated bowls, three bottles, six jars, six simple bowls, and three beakers. Only 18 percent of the burial vessels are plain, including three of the carinated bowls ( 30 percent) and two ( 28.6 percent) of the simple bowls.

The Burial 1 ceramic vessels include three carinated bowls, two bottles, two bowls, three jars, and a beaker (Figure 11a-k). The carinated bowls have engraved and incisedpunctated designs. The engraved carinated bowl (see Figure 11d) has a rectangular panel defined by closely spaced vertical and horizontal lines, creating what we call a "brick wall" design. The second vessel has a narrow scroll of incised lines filled with punctations, with the design repeated five times around the vessel (see Figure 11e). The third carinated bowl in Burial 1 has an incised rectilinear scroll design on the rim that is defined by slanting zones of closely spaced circular punctations (see Figure 11j); the design resembles examples of Pennington Punctated-Incised (see Suhm and Jelks 1962:Plate 61i).

Both bottles have curvilinear and circular engraved decorative elements, with connecting fill elements of either excised (see Figure $11 \mathrm{~b}$ ) or cross-hatched engraved designs (see Figure $11 \mathrm{k}$ ). These elements are a common fill element or feature in the Nacogdoches Engraved vessels from the Washington Square Mound site (cf. Hart 1982:Figure 3-4), and the most common engraved decorative element at the Oak Hill Village site (Perttula 1998); the engraved elements are often filled with a red or white clay pigment.

One of the two bowls has rectangular sets of punctated lines (see Figure 11f) resembling the decorative element on one Washington Square Paneled vessel from the Washington Square Mound site (Hart 1982:Figure 3-12b). The other bowl (see Figure 11i) has a broad, flat, and crenallated lip with engraved triangles on the lip; the body of the vessel is plain.

The three jars among the Burial 1 grave goods are a diverse group of vessels. One is a Handy Engraved jar with engraved and excised scrolls and concentric circles on the body, strap handles, and rows of punctations on the rim (see Figure 11c); the engraved lines are pigment-filled. The second is a medium-sized jar with punctated and brushed strap handles, a vertical brushed-punctated-appliqued body, and horizontal punctations and brushing on the rim (see Figure 11f). It resembles vessels of both Haley Complicated-Incised and Reavely Brushed-Incised (cf. Suhm and Jelks 1962:Plate 30; Hart 1982), but the simpler decorative elements on this Redwine vessel have closer stylistic affiliations to the Washington Square Mound Middle Caddoan type. The third Burial 1 jar is a small Killough Pinched vessel (see Figure $11 \mathrm{~g}$ ).

The beaker has engraved ladders and semi-circles repeated four times around the vessel (see Figure 11a). The engraved semi-circles are defined by a set of three lines, the inner two semi-circles filled with diagonal lines. Similar sherds and vessel sections have been recovered in Middle Caddoan contexts at the Oak Hill Village site (Perttula 1998).

There are four ceramic vessels from Burial 2, three jars, and a carinated bowl (Figure 12ad). All of the vessels are decorated.

One of the Burial 2 jars is a miniature with random punctations (see Figure $12 b$ ), one is a Killough Pinched vessel with a cut-down and reworked lip (see Figure 12d), and the third jar has a brushed body and an incised-punctated decorative element on the rim (see Figure 

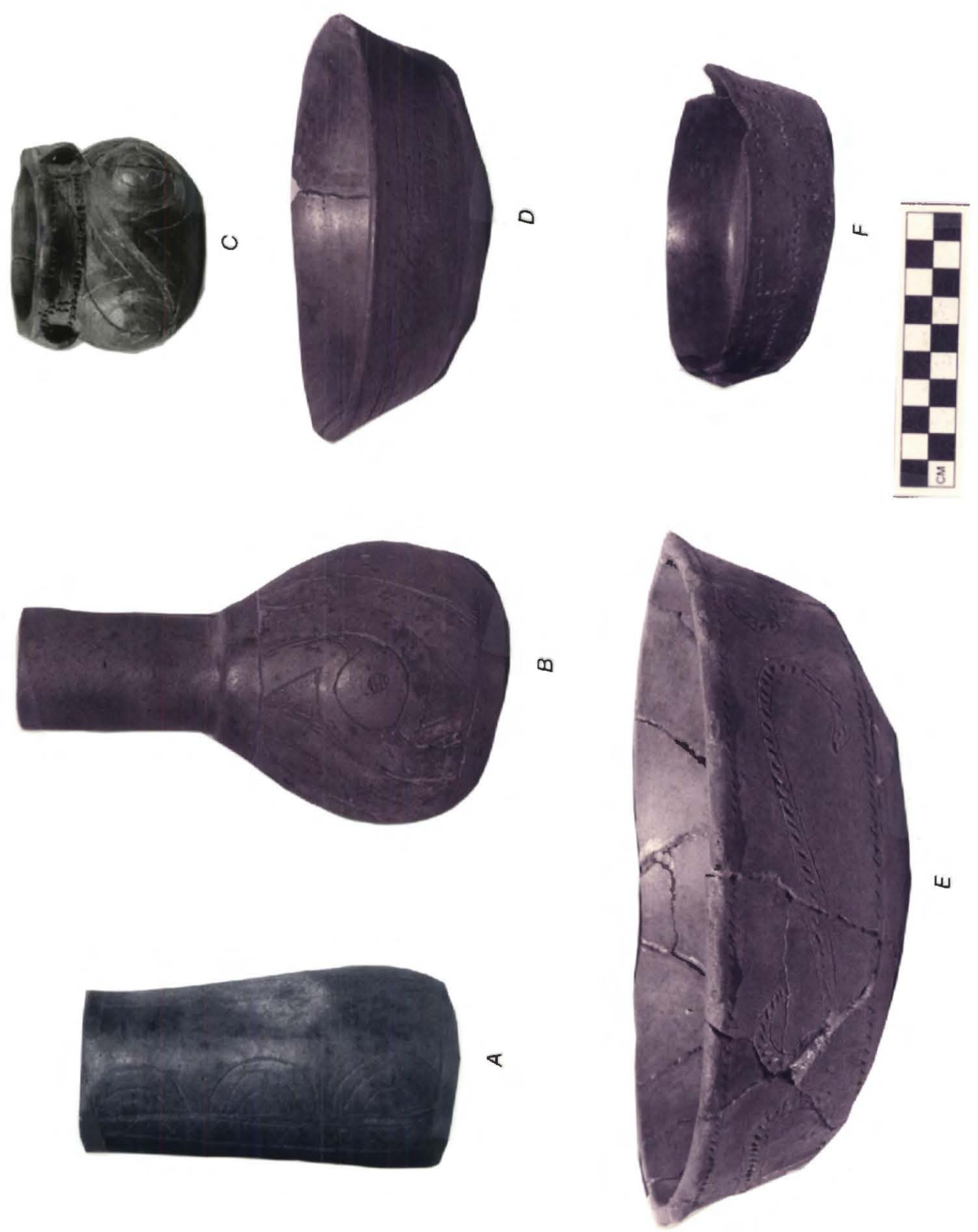

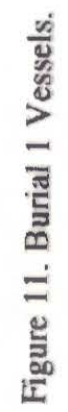




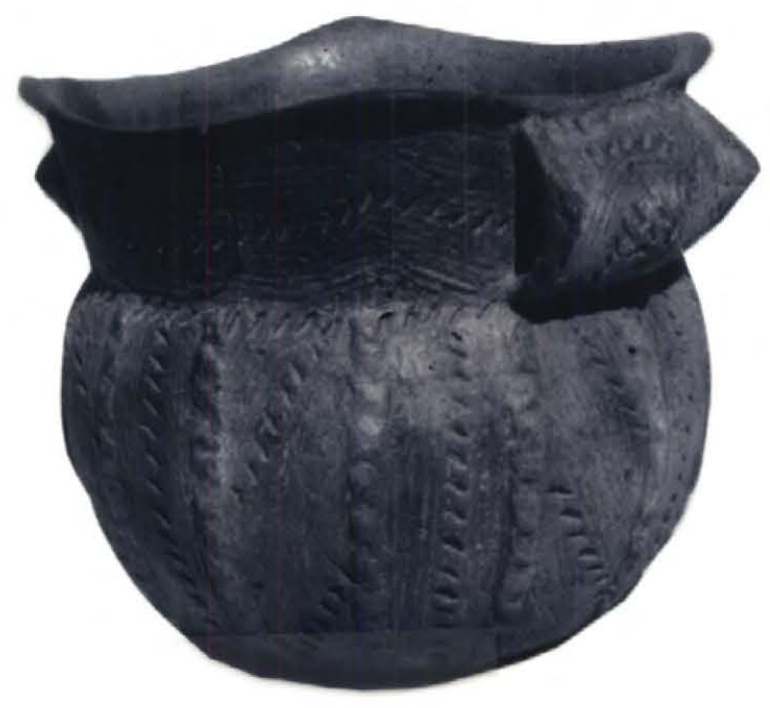

G
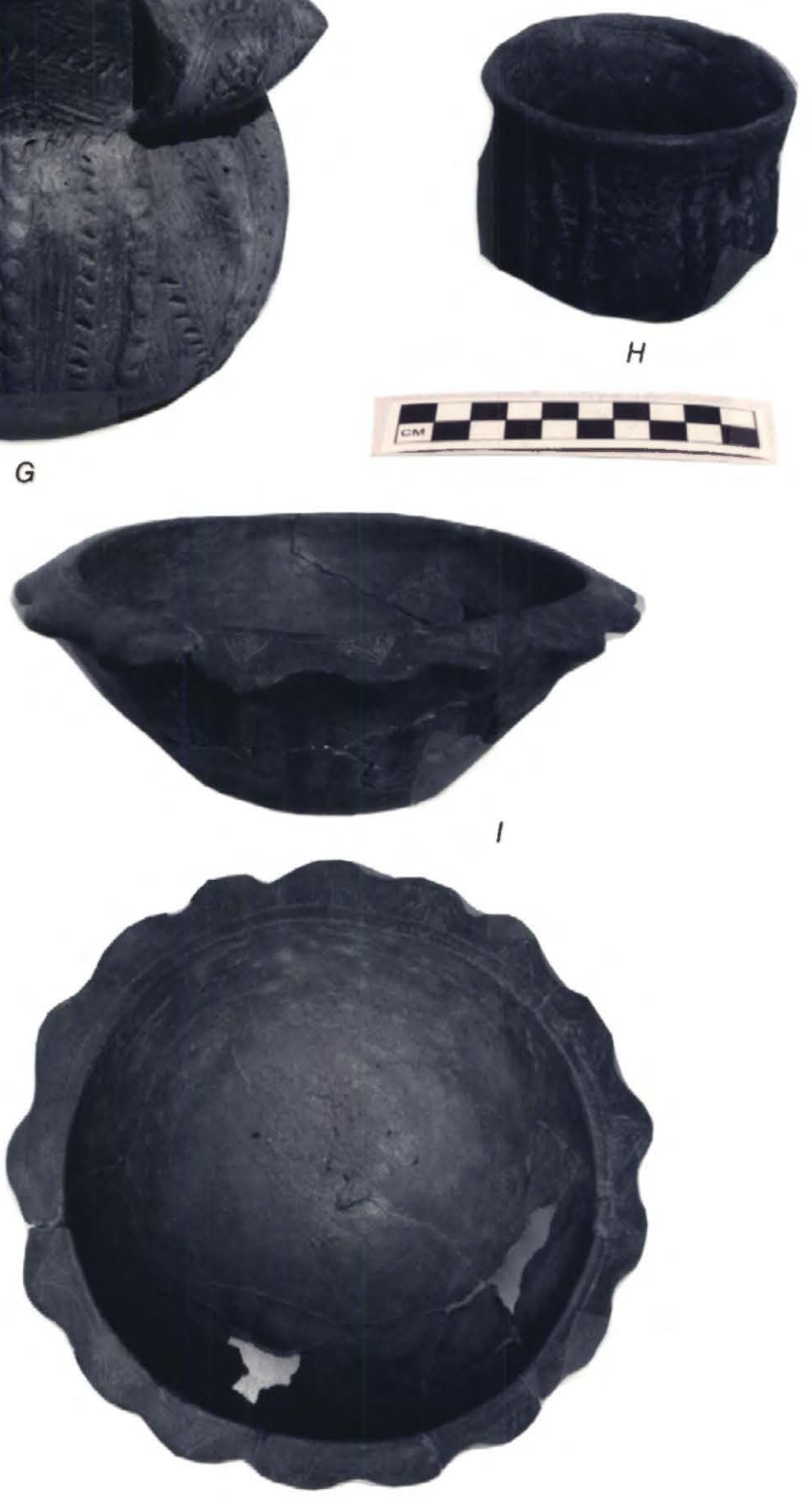

Figure 11, cont. 

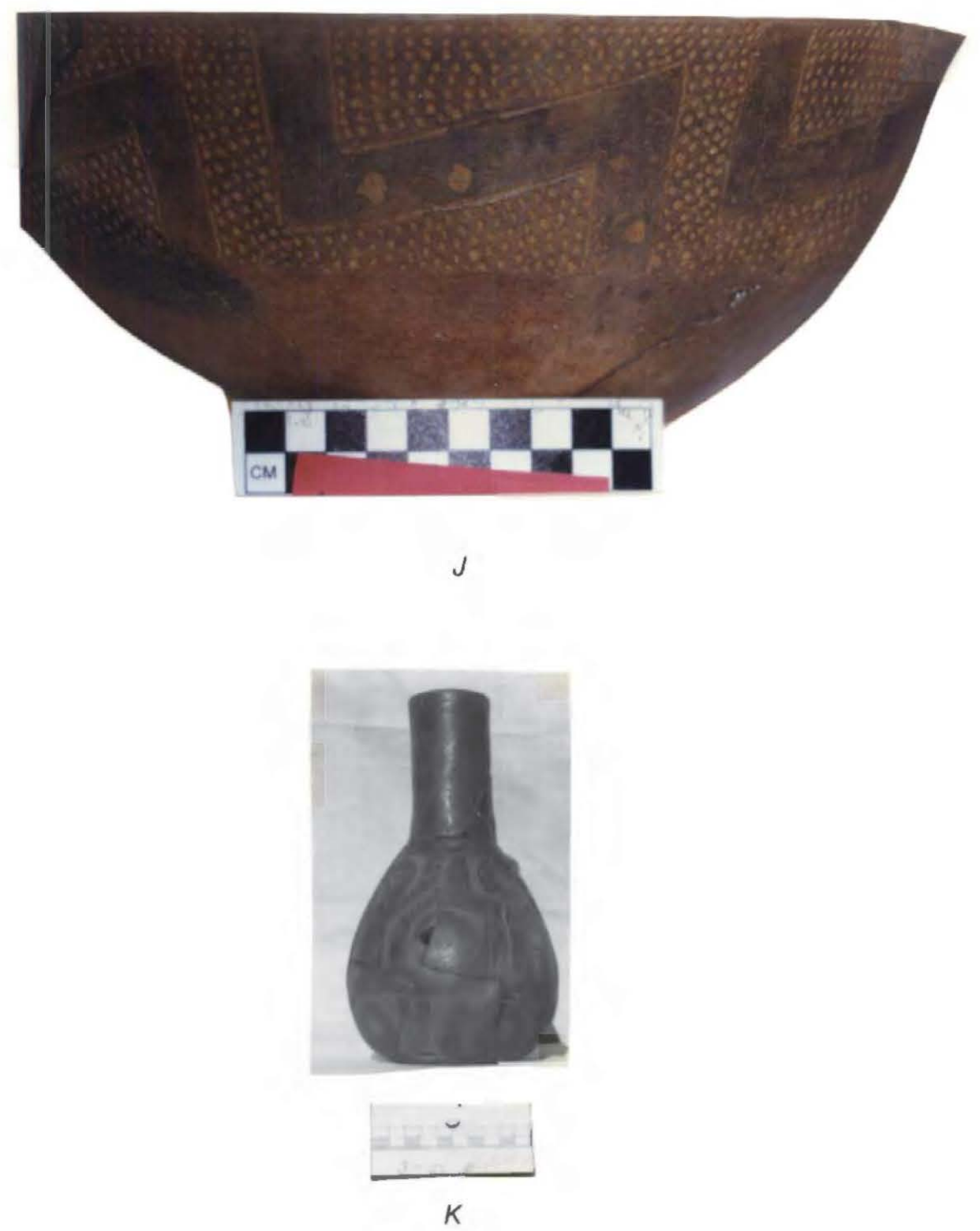

Figure 11, cont. 


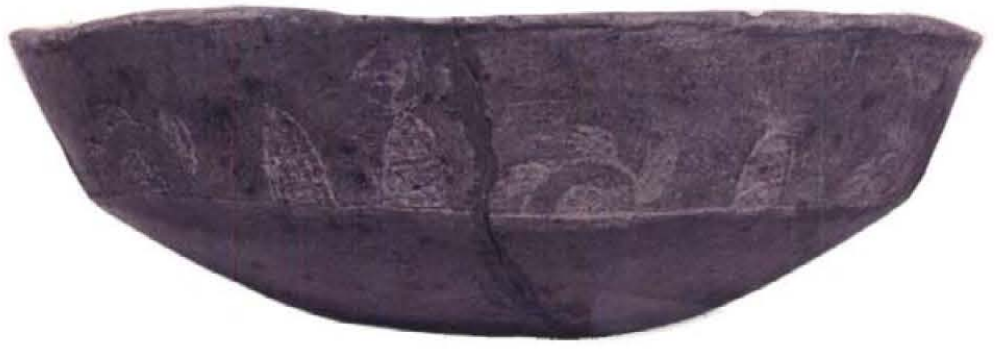

A

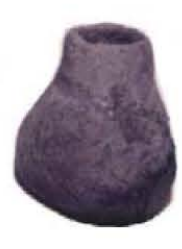

B

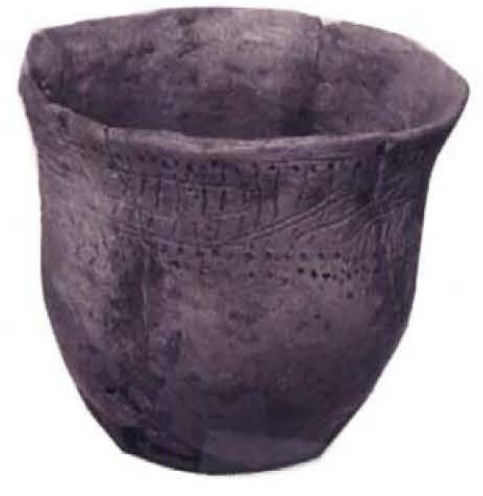

C

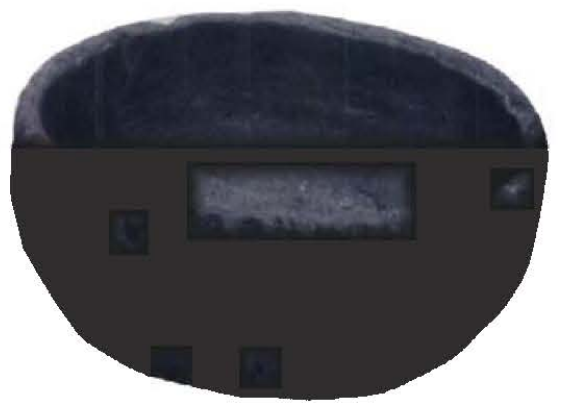

$D$

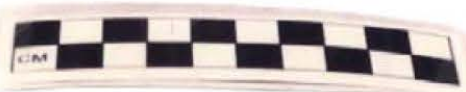

$R$

Figure 12. Burial 2 Vessels. 
12c). The element consists of a single row of punctations at the top of the rim, and two punctated rows at the rim-body juncture. Between them are alternating sets of vertical and diagonal incised lines; rim sherds with similar decorative elements are present in the Oak Hill Village ceramic assemblage (Perttula 1998). Killough Pinched sherds are not abundant at the Oak Hill Village site, accounting for only 1-2 percent of the $3850+$ decorated sherds.

The carinated bowl from Burial 2 has a unique engraved motif (see Figure 12a). The motif includes excised elements pendant from the carination that resemble the outlines of Caddoan wood "beehive-shaped" structures, along with engraved semi-circles with smaller excised elements.

Among the Burial 3 ceramic vessels are four carinated bowls, one bottle, three bowls, and a single beaker (Figure 13a-i). One of the carinated bowls is plain, although is has a notched lip (see Figure 13f), one is engraved, and the other two have incised-punctated decorative elements on the rim. The engraved vessel (see Figure 13a) has engraved scrolls with cross-hatched circles and semi-circular lines, and closely resembles a Nacogdoches Engraved vessel from Feature 95 at the Washington Square Mound site (Hart 1982:Figure 3-6d). The larger incised-punctated carinated bowl has circular and triangular elements (repeated five times around the rim) filled with punctations and divided by a scroll (see Figure 13d), and may be a Crockett Curvilinear Incised vessel. A vessel with a similar design has been identified at the Washington Square Mound site (Hart 1982:Figure 3-15c). The other incised-punctated carinated bowl has incised circles and narrow scrolls filled with punctations (see Figure 13e).

The bottle (see Figure 13c) has engraved scrolls divided by two vertical engraved panels or ladders filled with cross-hatched lines. Two of the bowls are plain (see Figure 13h-i), and the latter contained lumps of pigment. The larger plain bowl (see Figure 13h) has been smudged and burnished, and has a black exterior color. The other bowl is a bird effigy with two horizontal incised lines around the rim (see Figure $13 \mathrm{~g}$ ).

The beaker has scrolls and circles created by filling zones with cross-hatched engraved elements (see Figure 13b). Such elements are a common fill element or feature in the Nacogdoches Engraved vessels from the Washington Square Mound site (cf. Hart 1982:Figure 3-4), and the most common engraved decorative element at the Oak Hill Village site (Perttula 1998).

Burial 4 has four vessels, three carinated bowls and a beaker (Figure 14a-d). Two of the carinated bowls are plain, and one has two rim peaks (see Figure 14c). The engraved carinated bowl has a rectangular rim panel motif with engraved triangles at each corner of the panel, and an engraved circle in the center of the panel (see Figure 14a). The motif is repeated eight times around the rim. Similar sherds and/or vessels have been found in Middle Caddoan period contexts at the Washington Square Mound (Hart 1982:Figure 313b) and the Oak Hill Village (Perttula 1998) sites, and Hart (1982) refers to the design as "Mode A." The fourth vessel is a beaker with a horizontal incised panel on the rim, and the panel is filled with regularly-spaced incised lines (see Figure 14d).

\section{Ceramic Pipes}

Two of the three pipes are Red River, variety Haley long-stemmed pipes (Hoffman 1967), and the third is a flat-based elbow pipe, much like the elbow pipe bowl recovered in the midden excavations (Figure 15c). The Red River pipes, including one with a double bowl, were found with Burial 1, while the elbow pipe was a Burial 3 grave good. 


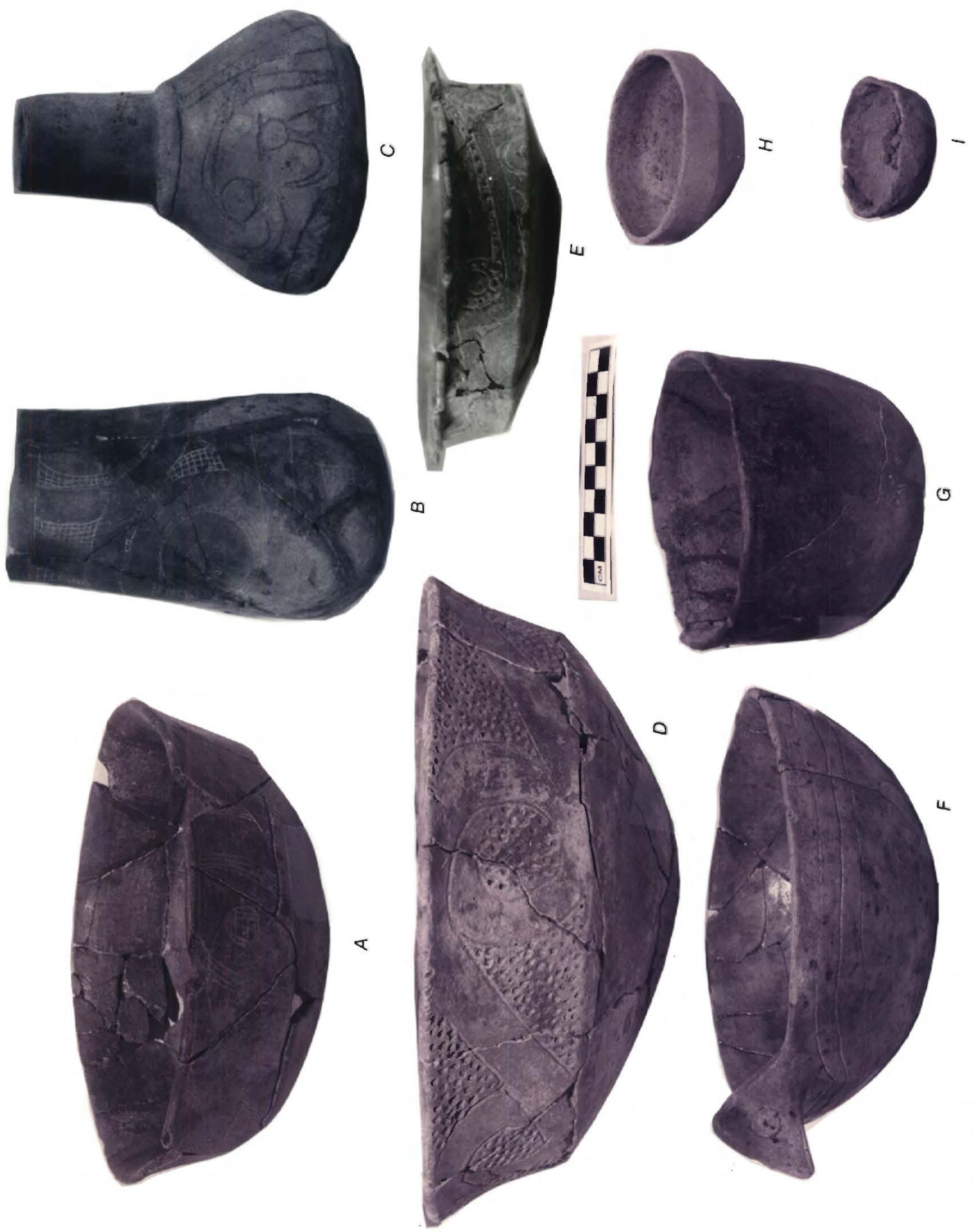

总 


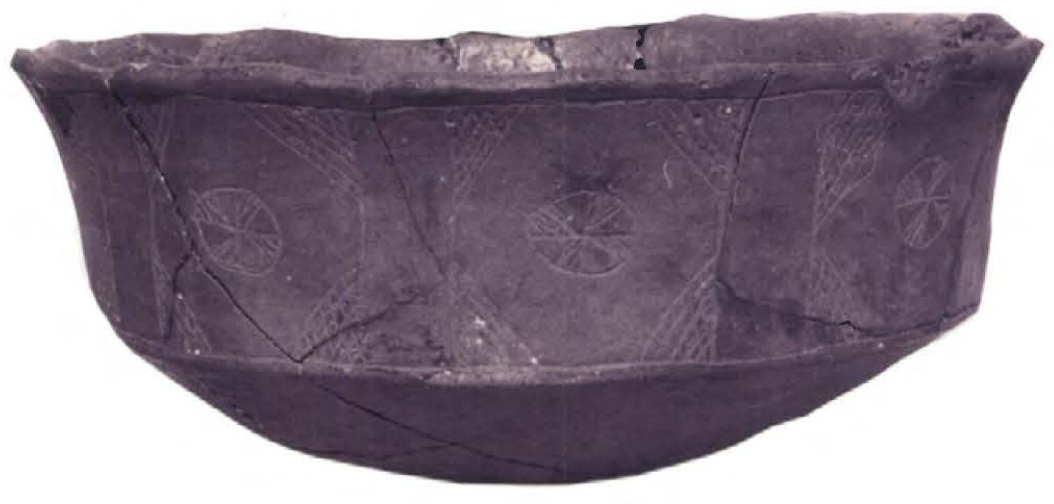

A

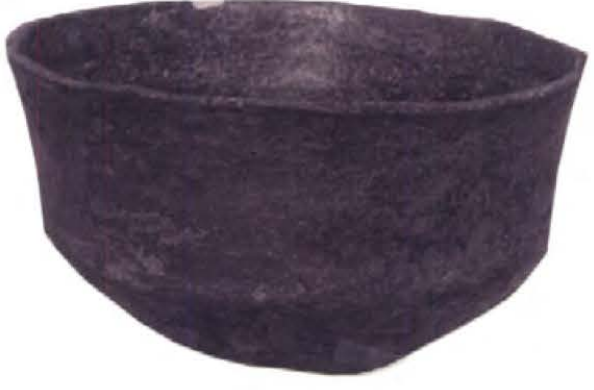

B

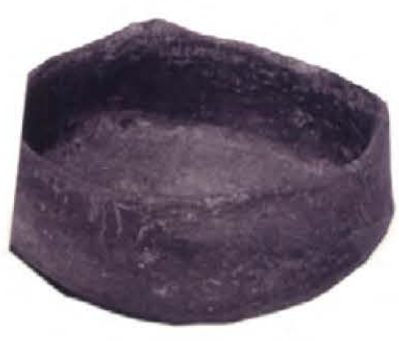

C

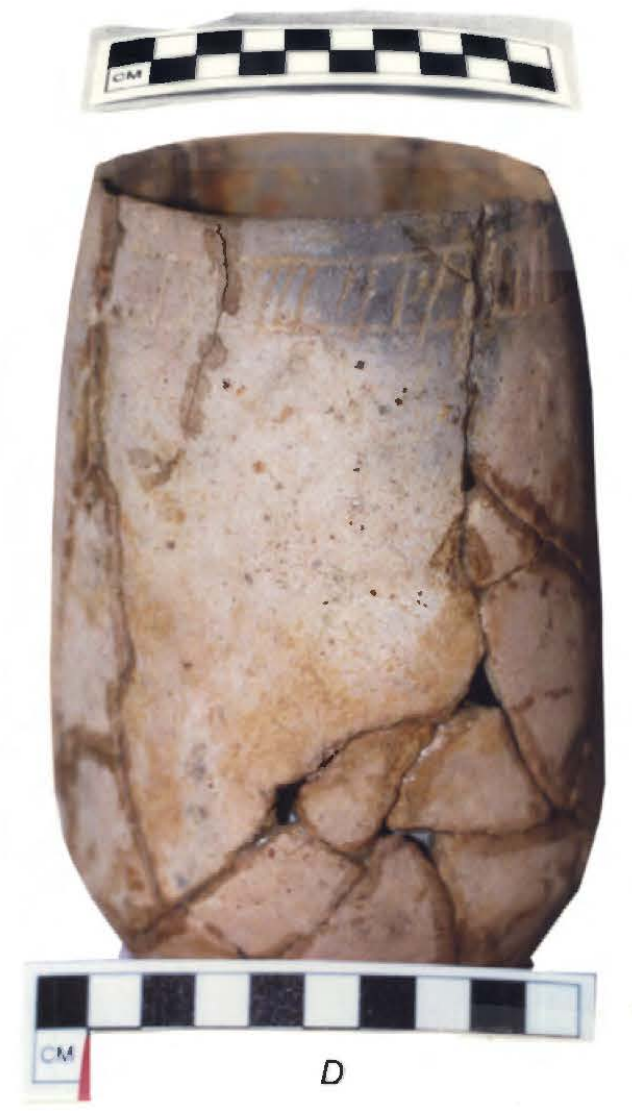

Figure 14. Burial 4 Vessels. 


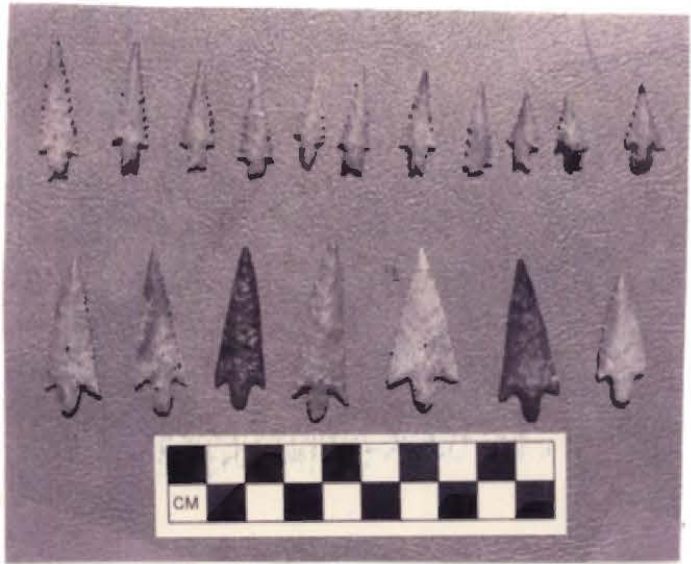

A

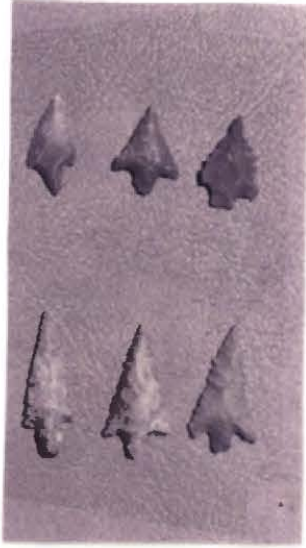

B

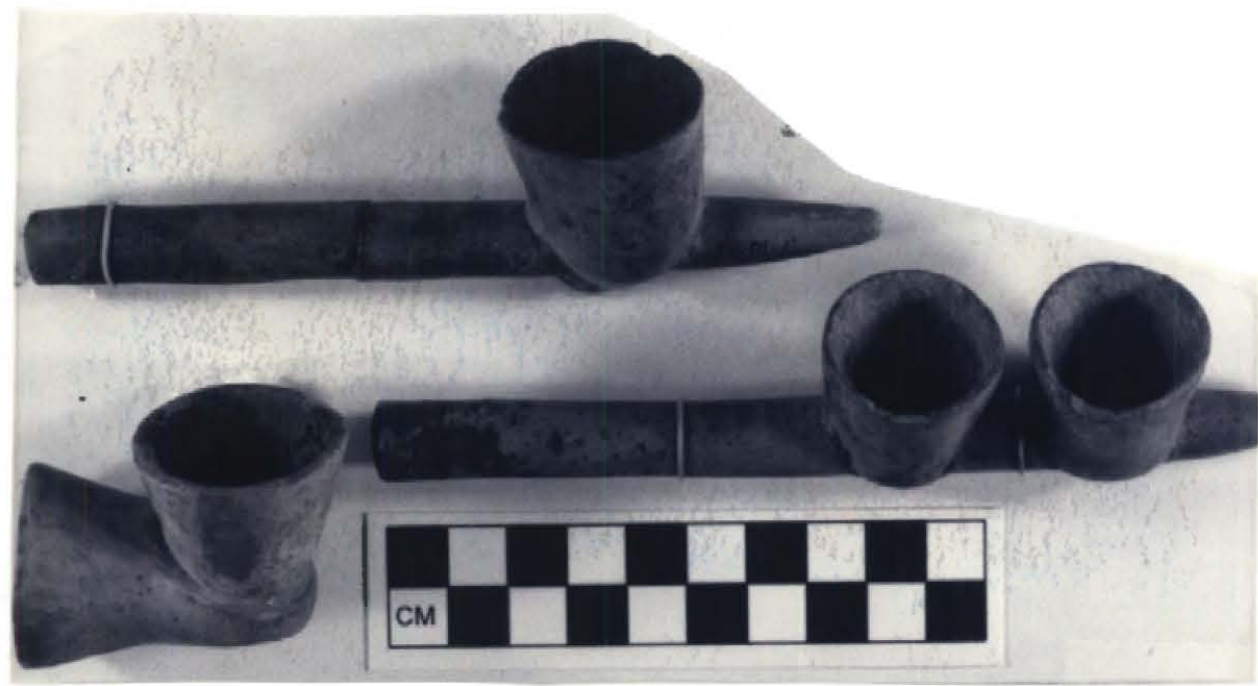

C

Figure 15. Arrowpoints and Pipes from Burials: a, Burial 1; b, Burial 3; c, Pipes from Burial 1 and 3. 


\section{Arrowpoints}

Burials 1 and 3 had numerous arrowpoints placed as grave goods, 18 in Burial 1 (see Figure 15a) and six in Burial 3 (see Figure 15b). In conjunction with the inclusion of clay pipes in these same burials, it is likely that Burials 1 and 3 were adult Caddo males.

All the arrowpoints in Burial 3 are of the Perdiz type, although one specimen may be a preform (see Figure 15b), along with seven points among the Burial 1 grave goods (see Figure 15a). The others are a distinctive shape, with narrow, parallel stems with a slightly concave base, and serrated blades (see Figure 15a). They resemble the Cuney type (see Turner and Hester 1993:210).

\section{Miscellaneous Lithic Items}

Included in this category are 42 pieces of lithic debris (including one flake tool), a piece of pink granite (?) raw material, a piece of pumice, a pink chalky or limestone rock with parallel carved lines, and one piece of smoothed hematite. This piece probably represents a source of pigment because the surface had an oval depression surrounded by faint scratch marks. These materials were found with Burial 3.

\section{Dates}

A single radiocarbon date was obtained from charred nutshells associated with the Feature 3 hearth. The $\mathrm{C} 14$ age of the nutshells is $570 \pm 50$ B.P. (Beta-91341); the corrected age (with a $\mathrm{C} 13 / \mathrm{C} 12$ ratio of $-25.0 \mathrm{o} / \mathrm{oo}$ ) remains $570 \pm 50 \mathrm{~B} . \mathrm{P}$. Calibrating the date utilizing Method A of the University of Washington calibration program (Stuiver and Reimer 1993) results in a two-sigma age range of $\mathrm{AD} 1304-1434$.

\section{Concluding Remarks}

The Redwine site has the potential to provide important information on Caddoan settlement and subsistence patterns in this area of the middle Sabine drainage basin. The site contains habitation areas, work areas, and ceremonial areas. The types of artifacts and features at Redwine suggest that the site was occupied on a year-round basis for at least 20 years, and the spatial pattern of artifacts and midden deposits are consistent with a community having 4-6 houses in a semi-circle around a vacant plaza area.

From the grave goods, there is indication of status ranking among the burials, and the ceramics placed with the deceased exhibit considerable stylistic motif variability. Red River and elbow pipes are present in habitation areas and burials. The single mound covered a circular structure with an extended entranceway, and its association with a carbon-stained soil suggests it may have been burned before being covered with a mound cap. Why do similar Middle Caddoan sites (such as Bryan Hardy, Oak Hill Village, and Tom Moore) have single house mounds, and are there Middle Caddoan sites in the Sabine River drainage that contain multiple mounds?

Artifacts recovered at the Redwine site point to interaction and trade with local groups, and no apparent ties with widespread trade networks, although some of the ceramic forms and styles (Red River pipes and Haley phase designs) may point to broader connections with the Red River. Similar artifact types from the Washington Square Mound (41NA49) are interpreted by Corbin and Hart (1998) as pertaining to local developments, but with a Haley phase flavor. Petrographic and neutron activation analyses of the Redwine ceramics 
are clearly called for to resolve the character of trade and interaction spheres, as neutron activation analyses of the Oak Hill Village ceramics indicate that they were drawn from a fairly broad region (Hector Neff, 1998 personal communication to Timothy K. Perttula).

More detailed archaeological surveys and investigations are needed in the vicinity of the Redwine site to understand its place in the local Caddoan community (or communities). Its location is similar to other known Middle Caddoan period sites in the area (i.e., 41SM54, 41SM194, and 41PN149) in that it is a considerable distance to a known water source, and on a high terrace with similar sandy loam soil types. Perhaps changes in prehistoric subsistence patterns (i.e., the increased importance of maize cultivation?) dictated the selection of these particular landforms. Directly across the creek is a small house site with the same kinds of ceramics, and within a five mile radius are five other sites with many of the same characteristics as Redwine. We hope in the future to develop a model that explains the nature of prehistoric Caddoan activities in this area, and also accounts for why this area was apparently abandoned following the Middle Caddoan period. Reasons why the Redwine site (and others in the area) was abandoned may include a depletion of natural resources, climatic changes, or a change in subsistence and technology (i.e., selection of better corn-producing lands), but none of these are clearly evident in the archaeological record.

\section{Acknowledgments}

We would like to thank the volunteers who gave their time and support for the project, including Dr. John Keller and crew, Dr. Tom Middlebrook, Dr. Brent Pemberton and family, and Dr. George Philley and family.

\section{References Cited}

Bartram, W.

1791 Travels Through North and South Carolina, Georgia, East and West Florida. James and Johnson, Philadelphia.

Cheatum, E. P. and J. Flook

1974 Unionid and Gastropod Shells from Deposits in Anderson, Cherokee, and Henderson Counties, Texas. In Archeological Investigations at Lake Palestine, Texas, by K. M. Anderson, K. Gilmore, O. F. McCormick III, and E. P. Morenon. Contributions in Anthropology No. 11. Department of Anthropology, Southern Methodist University, Dallas.

Corbin, J. E. and J. P. Hart

1998 The Washington Square Mound Site: A Middle Caddo Mound Complex in South Central East Texas. Bulletin of the Texas Archeological Society 69:47-78.

Core, H. A., W. A. Cote, and A. C. Day

1979 Wood Structure and Identification. Syracuse University Press, Syracuse, New York.

Correll, D. S. and M. C. Johnston

1979 Manual of the Vascular Plants of Texas. University of Texas at Dallas. 
Delorit, R. J.

1970 An Illustrated Taxonomy Manual of Weed Seeds. Agronomy Publications, River Falls, Wisconsin.

Dimbleby, G. W.

1967 Plants and Archaeology. Baker, London.

Elias, T. S.

1980 The Complete Trees of North America: Field Guide and Natural History. 'Times Mirror Magazines, New York.

Fritz, G. J.

1992 Archaeobotanical Remains from Five Sites on the Red River, Northeast Texas. Report submitted to the Department of Antiquities Protection, Texas Historical Commission, Austin.

Goldborer, S. E.

1995 More Macrobotanical Materials from Three Sites along the Red River, Northeast Texas: Ray (41LR135), Fasken (41RR14), and Roitsch (41RR16). Report submitted to the Department of Antiquities Protection, Texas Historical Commission, Austin.

1997 Botanical Remains from Redwine (41SM193), Smith County, Texas. MS on file with authors.

Harris, F. L. (editor)

1937 Lawson's History of North Carolina. Garrett and Massie, Richmond, Virginia.

Hart, J. P.

1982 An Analysis of the Aboriginal Ceramics from the Washington Square Mound Site, Nacogdoches County, Texas. M.A. thesis, Department of Anthropology, Northeast Louisiana University, Monroe.

Hatherly, D. 'T.

1993 Soil Survey of Smith County, Texas. United States Department of Agriculture, Soil Conservation Service, in cooperation with Texas Agricultural Experiment Station and Texas State Soil and Water Conservation Board, Washington, D.C.

Heartfield, Price, and Greene, Inc.

1988 DataRecovery at Site 41HS74. Heartfield, Price, and Greene, Inc., Monroe.

Hoffman, M. P.

1967 Ceramic Pipe Chronology Along the Red River Drainage in Southwestern Arkansas. The Arkansas Archeologist 8:4-14.

Howells, R. G., R. W. Neck, and H. D. Murray

1996 Freshwater Mussels of Texas. Inland Fisheries Division, Texas Parks and Wildlife Department, Austin.

Jones, V. H.

1949 Maize from the Davis Site: Its Nature and Interpretation. In The George C. Davis Site, Cherokee County, Texas, by H. P. Newell and A. D. Krieger, pp. 241-249. Memoirs No. 5. Society for American Archaeology, Kenosha, Wisconsin. 
Jurney, D. H.

1996 The Fauna from 41SM193, 1995 Excavations. MS on file with the authors.

Martin, A. C. and W. D. Barkley

1961 Seed Identification Manual. University of California Press, Berkeley.

Minnis, P. E.

1981 Seeds in Archaeological Sites: Sources and Some Interpretive Problems. American Antiquity 46(1): 143-152.

Montgomery, F. H.

1977 Seeds and Fruits of Plants of Eastern Canada and Northeastern United States. University of Toronto Press, 'Toronto.

Perttula, T. K.

1998 The Decorated Ceramics from the Oak Hill Village Site (41RK214), Rusk County, Texas. MS on file, Espey, Huston \& Associates, Inc., Austin.

Perttula, T. K. and J. B. Cruse

1997 The Caddoan Archaeology of the Sabine River Basin during the Middle Caddoan Period. Journal of Northeast Texas Archaeology 9:30-37.

Perttula, T. K., C. J. Crane, and J. E. Bruseth

1982 A Consideration of Caddoan Subsistence. Southeastern Archaeology 1(2):89-102.

Stuiver, M. and P. J. Reimer

1993 Extended ${ }^{14} \mathrm{C}$ Data Base and Revised CALIB $3.0{ }^{14} \mathrm{C}$ Age Calibration Program. Radiocarbon 35(1):215-230.

Suhm, D. A. and E. B. Jelks (editors)

1962 Handbook of Texas Archeology: Type Descriptions. Special Publication No. 1, Texas Archeological Society, and Bulletin No. 4, Texas Memorial Museum, Austin.

Tull, $\mathrm{D}$.

1987 A PracticalGuide to Edible and Useful Plants. Texas Monthly Press, Austin.

Turner, E. S. and T. R. Hester

1993 A Field Guide to Stone Artifacts of Texas Indians. 2nd Edition. Gulf Publishing Company, Houston.

Vines, R. A.

1982 Trees of North Texas. University of Texas Press, Austin. 